Review Article

\title{
Heat Shock Protein 72 Expressing Stress in Sepsis: Unbridgeable Gap between Animal and Human Studies-A Hypothetical "Comparative" Study
}

\author{
George Briassoulis, ${ }^{1}$ Efrossini Briassouli, ${ }^{2}$ Diana-Michaela Fitrolaki, ${ }^{1}$ Ioanna Plati, ${ }^{3}$ \\ Kleovoulos Apostolou, ${ }^{4}$ Theonymfi Tavladaki, ${ }^{1}$ and Anna-Maria Spanaki ${ }^{1}$ \\ ${ }^{1}$ Pediatric Intensive Care Unit, University Hospital, School of Health Sciences, University of Crete, \\ Voutes Area, 71110 Heraklion, Crete, Greece \\ ${ }^{2} 1$ st Department of Propaedeutic Internal Medicine, Laiko, University General Hospital, University of Athens, 17 Agiou Thoma, \\ 11527 Athens, Greece \\ ${ }^{3}$ Department of Clinical Chemistry, School of Medicine, University of Crete, Voutes Area, 71110 Heraklion, Crete, Greece \\ ${ }^{4}$ National and Kapodistrian University of Athens, First Critical Care Department, Evaggelismos Hospital, \\ Ipsilantou 45, 10676, Athens, Greece \\ Correspondence should be addressed to George Briassoulis; ggbriass@otenet.gr
}

Received 30 April 2013; Accepted 5 October 2013; Published 12 January 2014

Academic Editor: Wolfgang Neuhofer

Copyright (C) 2014 George Briassoulis et al. This is an open access article distributed under the Creative Commons Attribution License, which permits unrestricted use, distribution, and reproduction in any medium, provided the original work is properly cited.

\begin{abstract}
Heat shock protein 72 (Hsp72) exhibits a protective role during times of increased risk of pathogenic challenge and/or tissue damage. The aim of the study was to ascertain Hsp72 protective effect differences between animal and human studies in sepsis using a hypothetical "comparative study" model. Forty-one in vivo (56.1\%), in vitro (17.1\%), or combined (26.8\%) animal and 14 in vivo (2) or in vitro $(12)$ human $\mathrm{Hsp} 72$ studies $(P<0.0001)$ were enrolled in the analysis. Of the 14 human studies, 50\% showed a protective Hsp72 effect compared to $95.8 \%$ protection shown in septic animal studies $(P<0.0001)$. Only human studies reported Hsp72associated mortality $(21.4 \%)$ or infection $(7.1 \%)$ or reported results $(14.3 \%)$ to be nonprotective $(P<0.001)$. In animal models, any Hsp72 induction method tried increased intracellular Hsp72 (100\%), compared to $57.1 \%$ of human studies $(P<0.02)$, reduced proinflammatory cytokines (28/29), and enhanced survival (18/18). Animal studies show a clear Hsp72 protective effect in sepsis. Human studies are inconclusive, showing either protection or a possible relation to mortality and infections. This might be due to the fact that using evermore purified target cell populations in animal models, a lot of clinical information regarding the net response that occurs in sepsis is missing.
\end{abstract}

\section{Introduction}

Sepsis is an inflammation-induced syndrome resulting from a complex interaction between host and infectious agents. It is considered severe when associated with acute organ dysfunction, which accounts for the main cause underlying sepsis-induced death. Despite increasing evidence in support of antioxidant [1], anti-inflammatory [2], or immuneenhancing [3] therapies in sepsis, recent studies failed to establish a correlation between antiseptic pathway-based therapies and improvement of sepsis [4] or septic shock [5] or among immune-competent patients [6].

Rapid expression of the survival gene heat shock protein 72 (Hsp72) was shown to be critical for mounting cytoprotection against severe cellular stress, like elevated temperature [7]. Intracellular Hsps are upregulated in cells subjected to stressful stimuli, including inflammation and oxidative stress exerting a protective effect against hypoxia, excess oxygen radicals, endotoxin, infections, and fever [8]. Recent studies imply that different biological disease processes and/or 
simple interventions may interfere with high temperature stress, leading to different clinical outcome in patients with and without sepsis [9]. In septic patients, administration of antipyretics independently associated with 28-day mortality, without association of fever with mortality [9]. Importantly, fever control using external cooling was safe and decreased vasopressor requirements and early mortality in septic shock [10].

Inducible Hsp72 is also found extracellularly where it exhibits a protective role by facilitating immunological responses during times of increased risk of pathogenic challenge and/or tissue damage [11]. Experimental data provide important insights into the anti-inflammatory mechanisms of stress proteins protection and may lead to the development of a novel strategy for treatment of infectious and inflammatory disorders [12]. However, although overexpression of stress proteins signals danger to inflammatory cells and aids in immune surveillance by transporting intracellular peptides to immune cells [13], it has also been linked to a deleterious role in some diseases [14]. In addition, serum Hsp72 levels were shown to be modulated according to the patient oxidant status whereas increased serum Hsp72 was associated with mortality in sepsis [15].

The purpose of this basic research-related review in critical care is to document the available evidence on the role of Hsp72 in sepsis, reporting both the state of the art and the future research directions. It might be that potential therapeutic use of stress proteins in prevention of common stress-related diseases involves achieving optimal balance between protective and immunogenic effects of these molecules [16]. In this review, we will attempt to classify experimental and clinical studies on Hsp72 in sepsis and to compare their results on inflammation, organ function, and outcome; we will also briefly discuss the mechanisms on how stress proteins might exert their protective or negative role in the disease development and highlight the potential clinic translation in the research field.

\section{Materials and Methods}

Human or animal in vivo or in vitro studies examining the beneficial effect of intra- or extracellular Hsp72 expression in sepsis were included in this study. The PRISMA [17] search method for identification of studies consisted of searches of PubMed database (1992 to September 2012) and a manual review of reference lists using the search term: "Hsp70 or 72." The search output was limited with the search filter for any of: sepsis; severe sepsis; bacterial lipopolysaccharide (LPS); endotoxin. References in selected studies were examined also. The title and abstract of all studies identified by the above search strategy were screened, and the full text for all potentially relevant studies published in English was obtained. The full text of any potentially relevant studies was assessed by five authors (DMF, EB, IP, AK, and TT). The same authors extracted data from the published studies.

2.1. Statistical Analysis. Proportions of methods used and results findings were compared by the $\chi^{2}$ test. A two-sided alpha of 0.05 was used for statistical significance. The results were analyzed using SPSS software (version 20.0, SPSS, Chicago, IL, USA).

\section{Results}

Our search identified 411 PubMed titles and abstracts. After excluding duplicates, studies with no original data, or data insufficient to evaluate or those whose outcome was ischemia/reperfusion injury or others, 55 articles were finally included for analysis. The aim of this minireview was not to examine the quality of studies, but to describe induction methods and to compare in vivo and in vitro methods and results regarding a potential protective role for $\mathrm{Hsp} 72$ in human and animal sepsis.

3.1. Animals. Forty-one in vivo (23, 56.1\%), in vitro ( 7 , $17.1 \%)$, or combined $(11,26.8 \%)$ animal studies fulfilling the research criteria regarding the role of Hsp72 in sepsis were enrolled in analysis (Tables $1(\mathrm{a}), 1(\mathrm{~b})$, and $1(\mathrm{c})$ ). In only 6 studies transgenic animals $\left(4 \mathrm{Hsp}^{-/-}(9.8 \%), 2\right.$ overexpressing the human Hspal2b gene (4.9\%)) were used (14.6\%), all in mice $(P<0.03)$. Hsp72 induction methods used in rats differed from those used in mice $(P<0.0001)$. Hsp72 induction was attempted most often using heat shock (rats 9, 37.5\%; mice 2, 12.5\%), glutamine (Gln) (rats 7, 29.2\%; mice 4, 25\%; sheep 1,100\%), or combined Gln with additional inducer (rats 1, 4.2\%; mice 2, 12.6\%). In 7 rats Hsp72 was induced through adenoviral vector Hsp72 (AdHSP) $(3,12.5 \%$ of studies in rats) or various recombinant Hsp72 (rHsp72) preparations $(4,16.7 \%)$ compared to 3 mice studies where AdHSP, bovine rHsp72 preconditioning, or overexpressed Hsp72 within the intestinal epithelium was used (6.2\%). Hsp72 gene-transfected models $(3,18.8 \%)$ or cecal ligation and puncture (CLP) with LPS or injection of microorganisms $(2,12.5 \%)$ were used only in mice studies.

In more than half of the studies induction was attempted in a pretreatment mode $(10,62.5 \%$ for mice; $13,54.2 \%$ for rats induction after LPS injection or CLP), followed by a concomitant mode in rats $(6,25 \%)$ or a posttreatment one in mice $(4,25 \%)$. The different time intervals used before or after experimental sepsis, most often 1-2 hours, did not differ among groups. Preventive effect was achieved by most induction methods used in mice or rats (39/41, 95.1\%), irrespective of the challenge period or timing used (Figures 1(a) and 1(b)). Two studies, one carried out in sheep and one in rats, were inconclusive. In all septic animal models, any Hsp72 induction method tried increased intracellular Hsp72 (41/41, $100 \%)$, reduced proinflammatory cytokines (28/29 studies involving cytokine measurements), organ damage (27/27), clinical deterioration (19/20), and enhanced survival (18/18).

3.2. Patients. Only 14 human in vivo (2) and in vitro (12) Hsp72 studies were identified (Tables 2(a) and 2(b)): human peripheral blood mononuclear cells (hPBMC) 9 studies, 64.3\%; polymorphonuclear leukocytes (hPMNL) 2 studies, $14.3 \%$; lymphocytes (hPBLC) 1 study, $7.1 \%$; in vivo (children or adults' serum levels) 2 studies, $14.3 \%$. Of those, hPBMC 


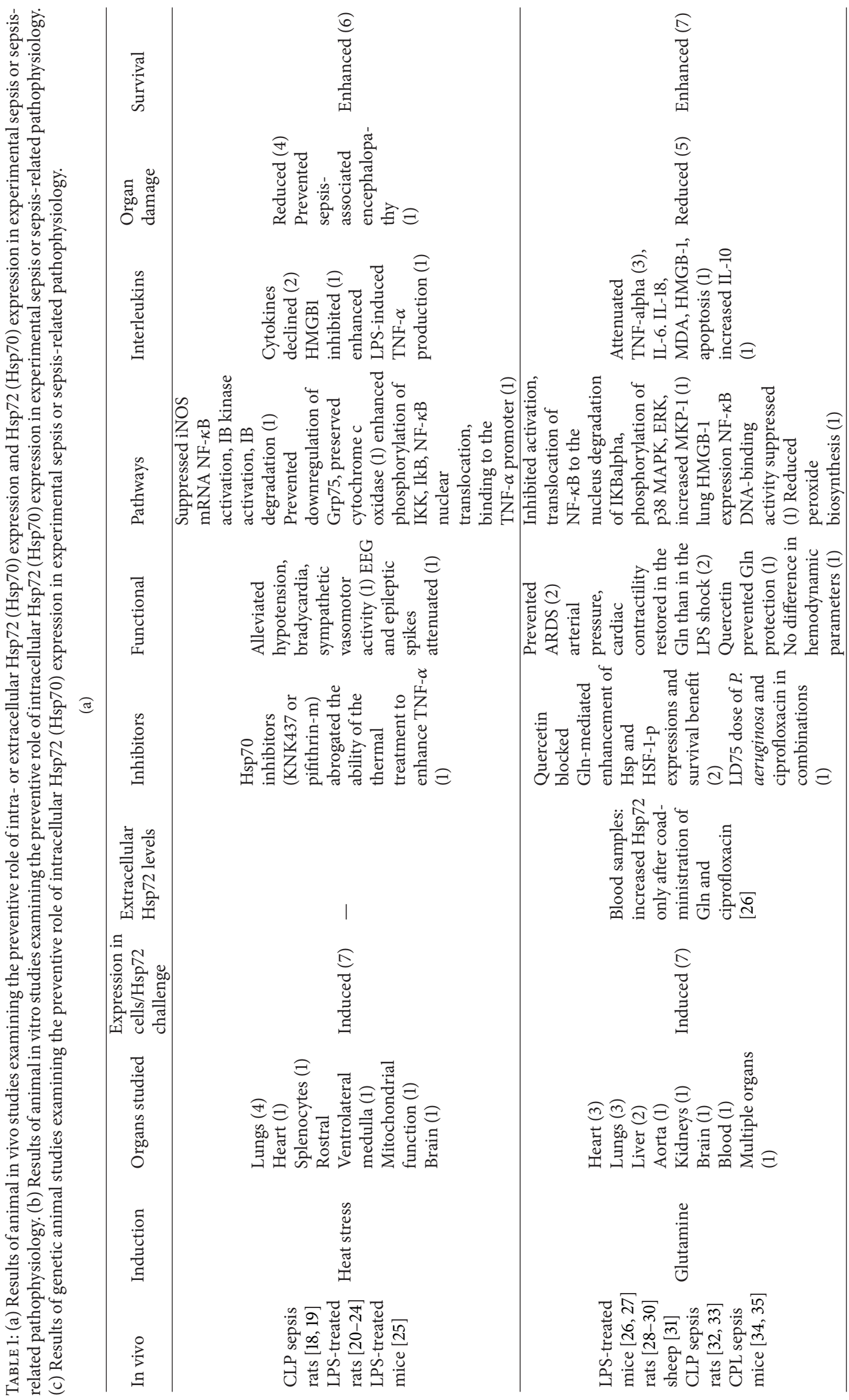




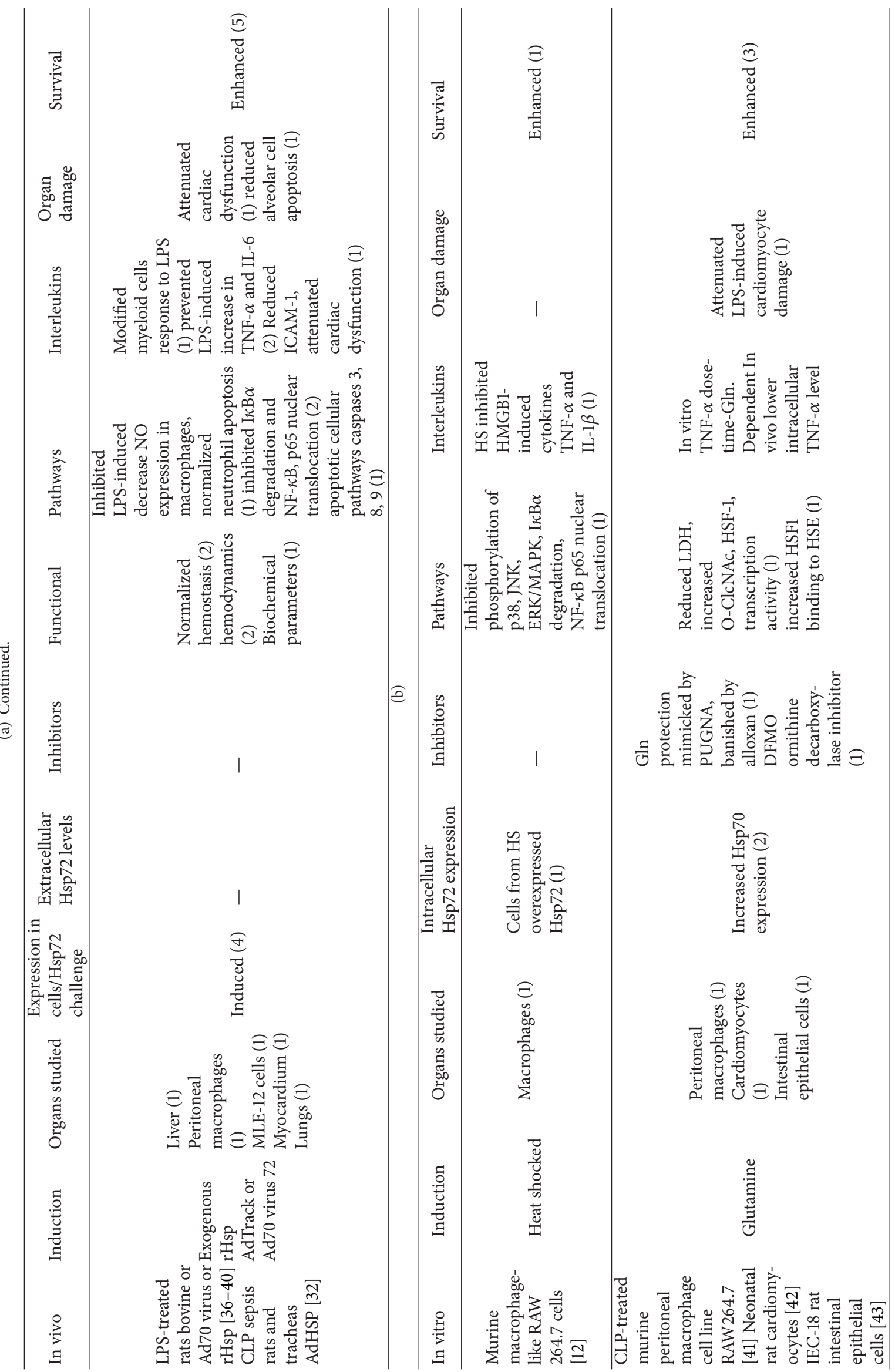




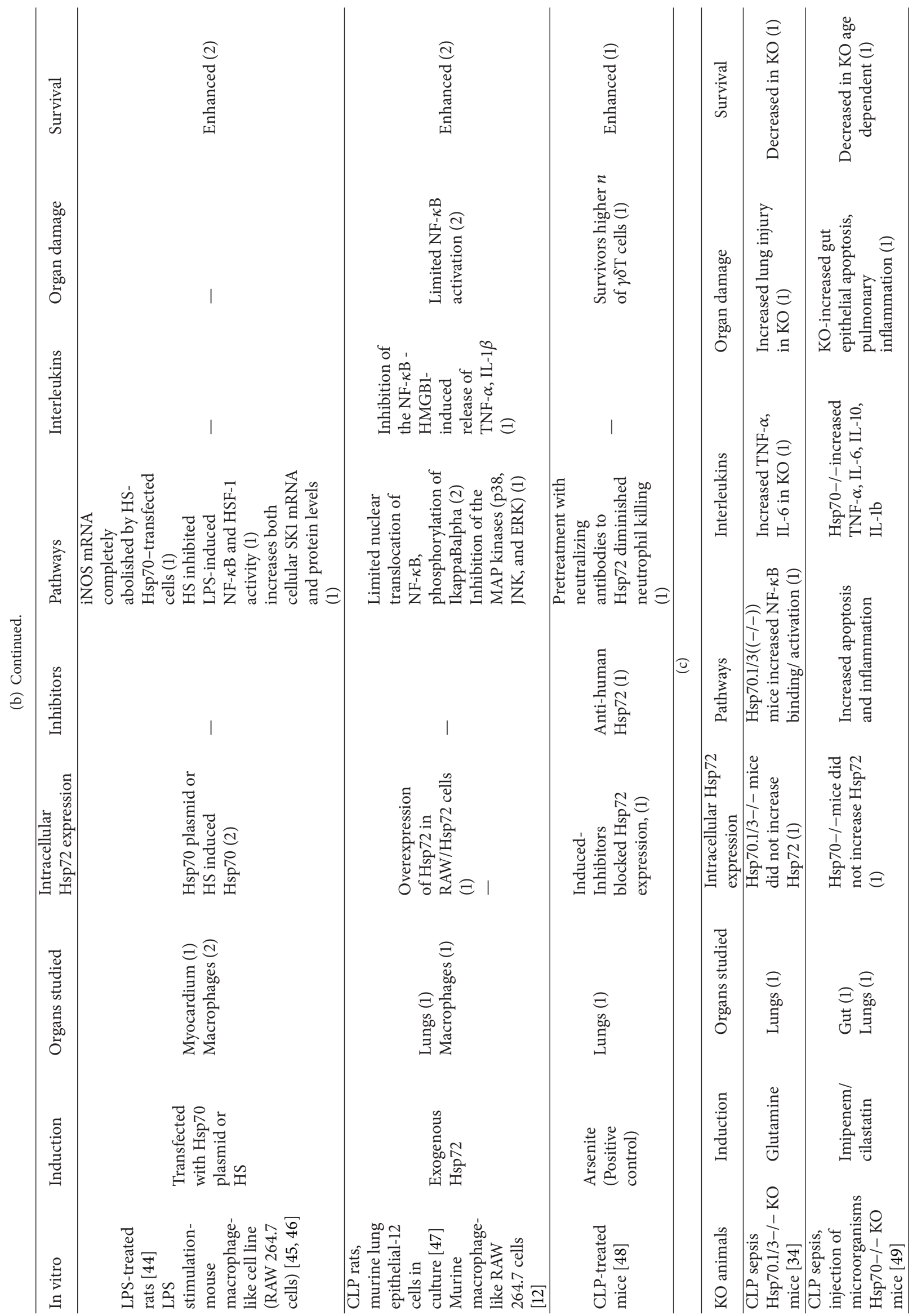




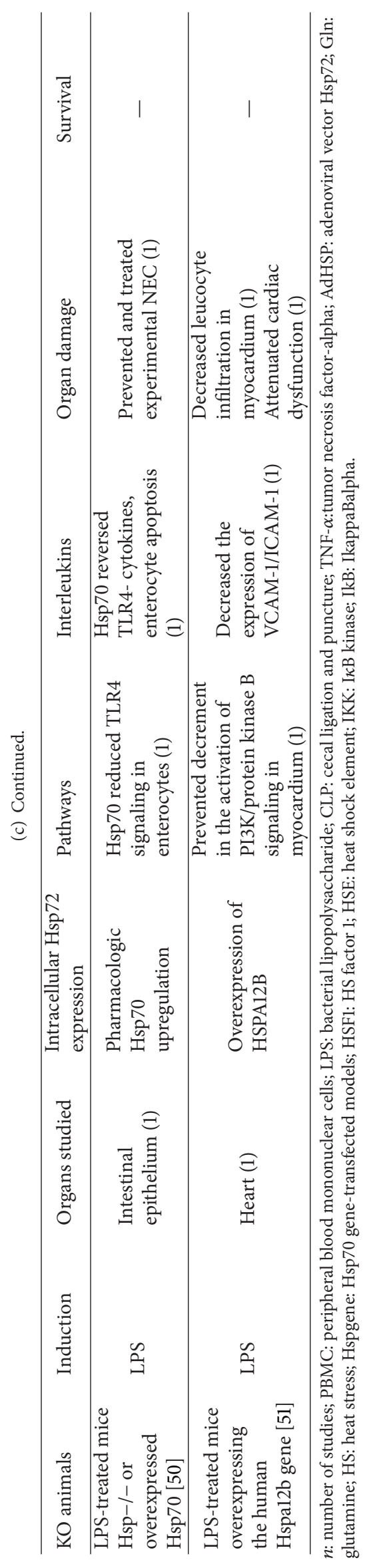




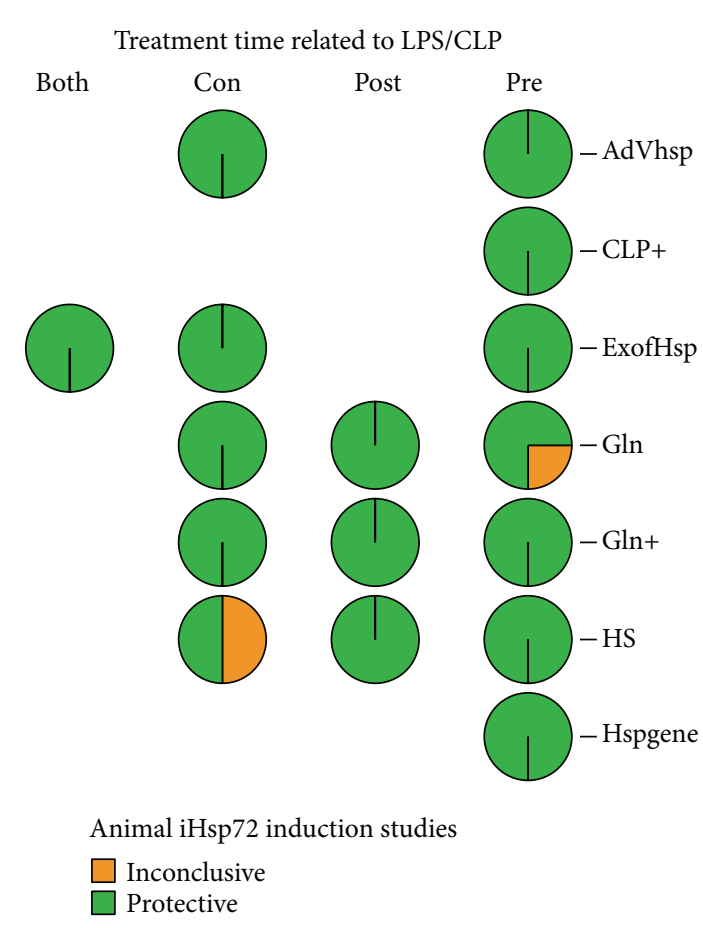

(a)

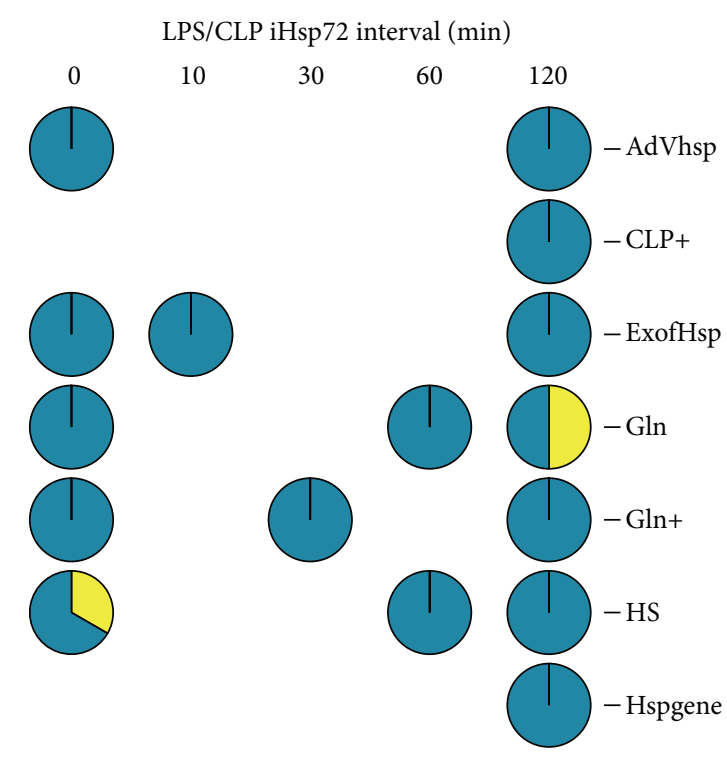

Animal iHsp72 induction studies

Inconclusive

Protective

(b)

Figure 1: (a) Preventive effect was achieved by all induction methods used irrespective of the challenge period or (b) time lapse between the sepsis insult and the Hsp72 induction: LPS, bacterial lipopolysaccharide; CLP, caecal ligation and puncture; iHsp72, inducible heat shock protein 72; Pre, pre-treatment; Post, posttreatment; both, trials with pre- and postexperiments; Con, concomitant; AdHSP, adenoviral vector Hsp72; exogHsp, exogenous Hsp72 preparations; Gln, glutamine; +, additional challenge; HS, heat stress; Hspgene, Hsp72 gene-transfected models.

were used in only 2 studies with septic patients but in 6 with healthy volunteers. Heat stress (HS) or acclimation was used in 5 studies (35.7\%), Gln administration in 2 in association with LPS (14.3\%), recombinant human Hsp72 in 1 (7.1\%), and either inhibitor or agonist in 1 (7.1\%). In 4 studies no challenge or only LPS (28.6\%) was used. In only 1 out of 6 $(16.7 \%)$ studies in septic patients induction Hsp72 methods were attempted compared to $100 \%$ in the studies with healthy (7) or ARDS $(1)$ patients $(P<0.006)$. Protection markers studied were apoptosis (3 studies, $21.3 \%$ ), HS (2 studies, $14.3 \%$ ), oxidative damage, hospital infections, hemodynamic instability, and ARDS (1 study each, 7.1\%).

Intracellular Hsp72 was induced in 8 in vitro studies (57.1\%, 6 in healthy, 2 in septic) and inhibited in 3 (21.4\%, 2 in septic, 1 in ARDS patients). Of the 6 studies in septic patients, intracellular Hsp72 was increased in 2 (33\%), inhibited in 2 (33\%), and not measured in 2 . With the exception of sodium arsenite, neither Gln nor HS were tested in these studies. Extracellular Hsp72, measured in 1 in vitro and in 2 in vivo studies, was shown to increase in sepsis, especially in septic shock or in those who died (14.3\% of human studies).

Increased intracellular Hsp72 was protective in half of the human studies (50\%); regarding the 9 positive (HS, Gln, exogenous Hsp72) in vitro induction Hsp72 human studies $7(77.8 \%)$ were protective (Figure 2(a)) and 2 inconclusive (11.1\%) or nonprotective (11.1\%). Of the induction methods used, protection offered HS $(4 / 5,80 \%)$, glutamine $(1 / 2,50 \%)$,
rHsp72 and sodium arsenite (1/1,100\% each) (Figure 2(b)). In contrast, of the 2 in vivo (serum Hsp72 measurements), 2 in vitro endotoxin induced (LPS or CLP), and 1 Hsp72 inhibitor human studies, none was shown to be associated with a better outcome $(P<0.02)$; 3 studies were associated with mortality $(60 \%)$ and 1 with infection (20\%) or were inconclusive $(20 \%)$. Septic patients' studies were positive for protection in only 1 out of $6(16.7 \%)$ compared to 5 out of $7(71.4 \%)$ in healthy and $100 \%$ in ARDS patients $(P<0.06)$.

3.3. Human Compared to Animal Studies. Out of a total of 55 enrolled studies, only 2 in vivo human studies (3.6\%) have been reported on the role of Hsp72 in sepsis compared to 7 mice $(12.7 \%)$ and 15 rat $(27.3 \%)$ in vivo studies $(P<0.0001)$; in contrast 12 human $(21.8 \%)$ studies have been reported in vitro compared to only 2 in rats $(3.6 \%)$ and 5 in mice (9.1\%); 4 mice $(7.3 \%)$ and 7 rat $(12.7 \%)$ combined in vitroin vivo studies have also been reported. Of the 14 human studies, 50\% showed a protective Hsp72 effect compared to $95.8 \%$ protection shown in animal studies (Figure 3(a)). When restricted to the septic patients' studies, however, only 1 out of $6(16.7 \%)$ demonstrated an Hsp72 protective effect compared to $95.8 \%$ protection shown in animal studies $(P<$ $0.0001)$. In addition, only human studies reported Hsp72associated mortality $(21.4 \%)$ or infection $(7.1 \%)$ or reported results $(14.3 \%)$ to be nonprotective $(P<0.001)$. 


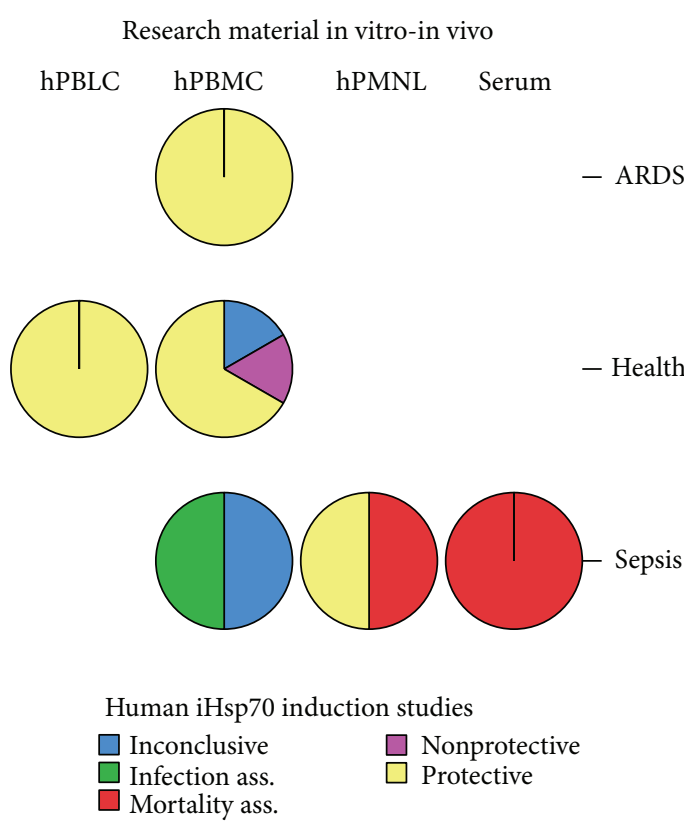

(a)

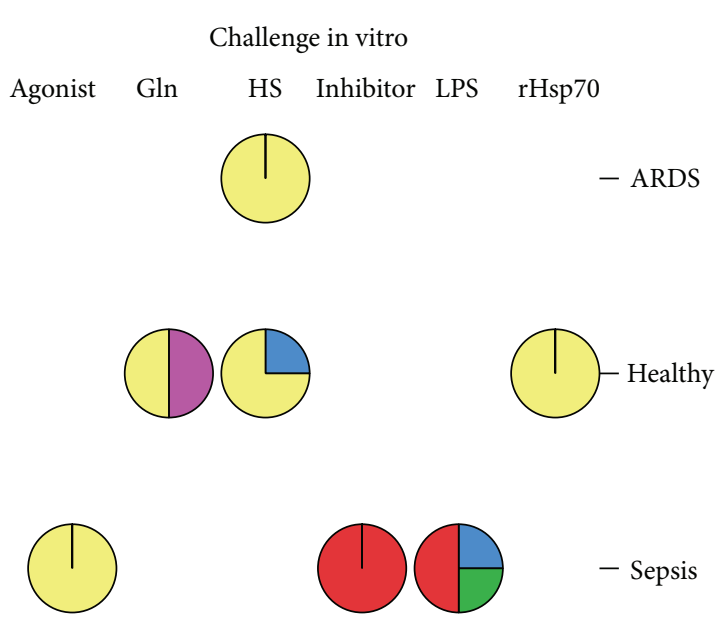

Human iHsp70 induction studies
$\square$ Inconclusive $\quad \square$ Nonprotective
$\square$ Infection ass.
$\square$ Mortality ass.

(b)

Figure 2: (a) Increased serum Hsp72 in septic patients was associated with mortality whereas human cell studies with Hsp72 induction were either inconclusive or protective or even partially associated with mortality and infection; (b) heat pretreatment and/or glutamine incubation and recombinant or Hsp72 agonists (sodium arsenite) partially protected human cells compared to the nonchallenged human cells or to those challenged with Hsp72 inhibitors (quercetin) or LPS alone $(P<0.04)$. Positive Hsp72 induction human in vitro studies were tried in healthy individuals or ARDS patients compared with 1 study in septic patients' cells $(P<0.02)$ whereas negative human Hsp72 studies (LPS, quercetin) or neutral studies (no induction) were only examined in septic human cells: iHsp72, inducible heat shock protein 72; hPBMC, human peripheral blood mononuclear cells; hPMNL, human peripheral polymorphonuclear leukocytes; hPBMC, human peripheral blood lymphocytes; ARDS, acute respiratory distress syndrome; Gln, glutamine; HS, heat stress; LPS, bacterial lipopolysaccharide; rHsp72, recombinant Hsp72.

Most of the human studies were prospective observational experimental controlled studies $(57.1 \%)$ and only 1 randomized study (7.1\%) compared to prospective controlled animal studies $(100 \%, P<0.0001)$. All other human studies were experimental control (14.3\%) or noncontrolled (14.3\%) studies. Induction methods used differed significantly $(P<$ $0.02)$, increasing $\mathrm{Hsp} 72$ in $57.1 \%$ of the human as compared to $100 \%$ of animal studies $(P<0.02)$. Only $6(42.9 \%)$ human studies included septic patients compared to 41 $(100 \%$ experimental sepsis $)$ in animal studies $(P<0.0001)$. Although differed among Hsp72 study populations $(P<$ $0.001)$ or methodology selected $(P<0.02)$, the various induction methods used did not affect the Hsp72 offered protection (Figures $3(\mathrm{~b})$ and $3(\mathrm{c})$ ).

\section{Discussion}

Hsps70 are emerging as powerful dichotomous immunemodulatory molecules that can have stimulatory and inhibitory effects on immune responses [63]. In our hypothetical "comparative study" model, we found that the balance between Hsp72 promotion and control of inflammatory responses and sepsis outcome differed unpredictably between human and animal studies. Clinical studies were inconclusive, showing either a low probability of protection $(16.7 \%$ among septic patients) or even a possible relation to mortality and infections. In contrast, almost all (94.7\%) septic animal in vivo and in vitro studies showed a biochemical, biological, and clinical protective effect for Hsp72 in sepsis. This might be due to the fact that using evermore purified target cell populations to provide insight into the direct effects of molecules on cells, a lot of clinical information regarding the net response that occurs in vivo is missing [63].

4.1. Stress Proteins Induction. Sepsis, endotoxin tolerance, and heat shock all display downregulation of innate immunity, sharing a common immune suppressive effect, possibly through HS factor 1 (HSF1) mediated competitive inhibition of nuclear factor kappa-B (NF- $\kappa$ B) binding [45]. It has been shown that multiple chaperones or cochaperones, including Hsp72, tend to form a complex with HSF1 monomers [64]. Once a cell is exposed to stress, these chaperones and cochaperones bind to denatured and damaged proteins, thereby "releasing" the nonactive HSF1 monomers to subsequently undergo homotrimerization [65]. However, while homotrimerization is sufficient for DNA binding and nuclear translocation, the magnitude and duration of transcriptional activity are regulated by inducible phosphorylation of specific serine residues of HSF1 by several protein kinases (Erk1/2, glycogen synthase kinase, protein kinase C) [64]. 


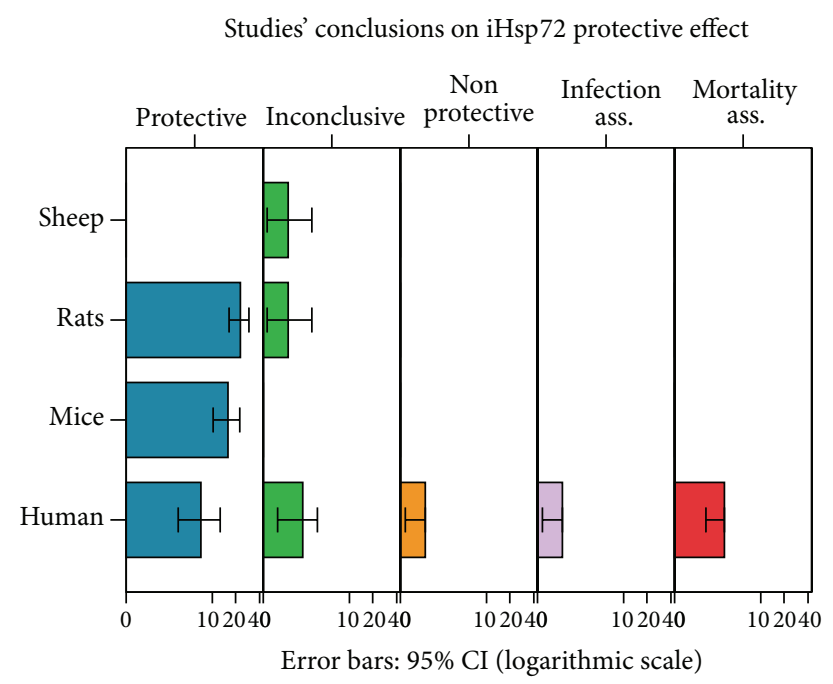

(a)

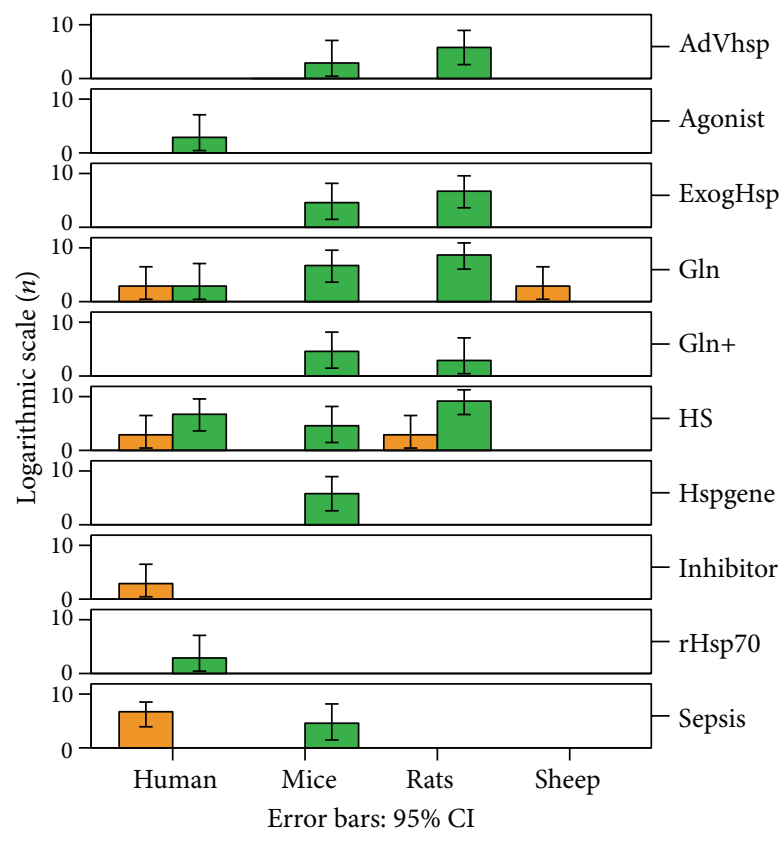

iHsp72 induction methods

$\square$ Nonprotective

$\square$ Protective

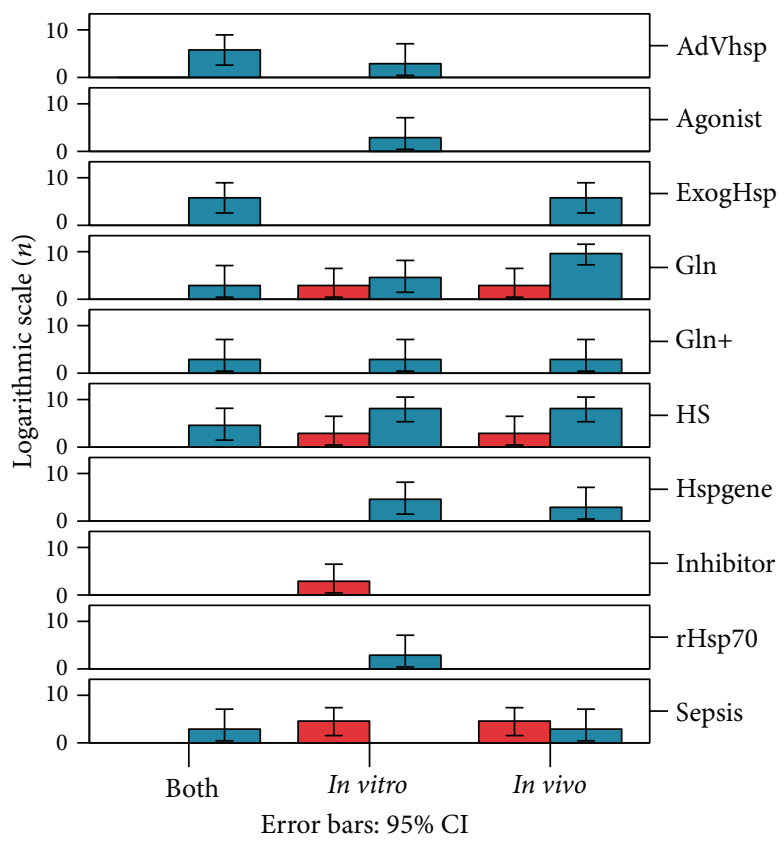

iHsp72 induction methods $\square$ Nonprotective Protective

(b)

(c)

FIGURE 3: (a) Diagram showing summaries of conclusions regarding the Hsp72 protective effects in sepsis in human and animal studies $(P<$ 0.008); (b) human Hsp72 induction methods showed inconsistent results compared to the unanimous Hsp72 protective results in experimental sepsis with any attempted induction method; selection of any induction method, however, did not affect results; (c) Hsp72 induction protective effect using various induction methods was not influenced by the in vitro, in vivo, or combined study method selected: iHsp72, inducible heat shock protein 72; AdHSP, adenoviral vector Hsp72; exogHsp, exogenous Hsp72 preparations; Gln, glutamine; +, additional challenge; HS, heat stress; rHsp72, recombinant Hsp72; Hspgene, Hsp72 gene-transfected models; both, in vitro and in vivo experiments.

Once inside the nucleus, HSF1 binds to a heat shock element (HSE) in the promoter of Hsp genes, which is defined by a tandem repeat of the pentamer nGAAn arranged in an alternating orientation either "head to head" (e.g., $5^{\prime}$-nGAAnnTTCn-3') or "tail to tail" (e.g., $5^{\prime}$-nTTCnnGAAn-3') [66], resulting in the upregulation of stress protein gene expression [67]. Thus, the intracellular accumulation of denatured or improperly folded proteins in response to stress is believed to be the universal signal resulting in the stressinduced gene expression of stress proteins $[68,69]$ which is proportional to the severity of the stress [70]. Besides the innate immune response stress proteins seem to activate 
TABLE 2: (a) Human in vivo studies relating intra- or extracellular Hsp72 (Hsp70) expression to outcome in sepsis. (b) Human in vitro studies relating intracellular Hsp72 (Hsp70) expression to outcome in sepsis.

(a)

\begin{tabular}{|c|c|c|c|c|c|}
\hline In vivo & $\begin{array}{l}\text { Study popula- } \\
\text { tion/material }\end{array}$ & $\begin{array}{l}\text { Expression in } \\
\text { cells/Hsp } 72 \text { challenge }\end{array}$ & Extracellular Hsp72 levels & $\begin{array}{l}\text { Hsp72 is associated } \\
\text { with }\end{array}$ & $\begin{array}{l}\text { Conclusion on the } \\
\text { Hsp72 role in sepsis }\end{array}$ \\
\hline $\begin{array}{l}\text { Patients with } \\
\text { septic shock } \\
{[15,52]}\end{array}$ & $\begin{array}{l}\text { Children with } \\
\text { septic shock (1), } \\
\text { adults with severe } \\
\text { sepsis (1) }\end{array}$ & - & $\begin{array}{l}\text { Elevated in septic shock (1) } \\
\text { nonsurvivors (1) } \\
\text { pronounced oxidative } \\
\text { damage (1) }\end{array}$ & $\begin{array}{l}\text { Septic } \\
\text { shock-mortality (2) } \\
\text { modulated according } \\
\text { to oxidant status (1) }\end{array}$ & $\begin{array}{l}\text { Related to mortality } \\
\text { (2) patient oxidant } \\
\text { status (1) }\end{array}$ \\
\hline $\begin{array}{l}\text { Healthy } \\
\text { young men } \\
\text { Gln-LPS [53] }\end{array}$ & $\begin{array}{l}\text { Crossover study: } \\
\text { Hsp70 in PBMCs } \\
\text { (1) }\end{array}$ & $\begin{array}{l}\text { Gln did not affect } \\
\text { Hsp70 in PBMCs (1) }\end{array}$ & - & $\begin{array}{l}\text { Gln did not affect } \\
\text { LPS-WBC, TBF- } \alpha \text {, } \\
\text { IL- } 6 \text {, temperature } \\
\text { heart rate alterations }\end{array}$ & $\begin{array}{l}\text { Not protective in } \\
\text { experimental sepsis } \\
\text { (1) }\end{array}$ \\
\hline
\end{tabular}

\begin{tabular}{|c|c|c|c|c|}
\hline In vitro & Study population/material & $\begin{array}{l}\text { Expression in } \\
\text { cells/Hsp } 72 \text { challenge }\end{array}$ & $\begin{array}{l}\text { Hsp70 is associated } \\
\text { with }\end{array}$ & $\begin{array}{l}\text { Conclusion on the } \\
\text { Hsp72 role in sepsis }\end{array}$ \\
\hline $\begin{array}{l}\text { PBMCs-Hsp } \\
\text { inhibitor-inducers } \\
{[54,55]}\end{array}$ & $\begin{array}{l}\text { PBMCs } 24 \text { hours after } \\
\text { sepsis (1) sodium arsenite } \\
\text { (inducer of Hsp) and } \\
\text { quercetin (suppressor of } \\
\text { Hsp) to regulate expression } \\
\text { of Hsp70 in PMNLs (1) }\end{array}$ & $\begin{array}{l}\text { Hsp70 increased (1) } \\
\text { prevented by } \\
\text { quercetin (1) }\end{array}$ & $\begin{array}{l}\text { Enhanced TNF- } \alpha \text { (1) } \\
\text { increased oxidative } \\
\text { activity, inhibited } \\
\text { apoptosis (1) }\end{array}$ & $\begin{array}{l}\text { Inconclusive (1) may } \\
\text { inhibit apoptosis (1) }\end{array}$ \\
\hline LPS-PBMC [56] & $\begin{array}{l}\text { LPS inducibility of Hsp70 } \\
\text { expression in the PBMC }\end{array}$ & $\begin{array}{l}\text { Inhibits Hsp70 } \\
\text { expression in PBMC } \\
\text { (in septic patients } \\
\text { more than in } \\
\text { controls) }\end{array}$ & $\begin{array}{l}\text { Decreased resistance } \\
\text { to infectious insults } \\
\text { during severe sepsis }\end{array}$ & $\begin{array}{l}\text { May be related to } \\
\text { infections }\end{array}$ \\
\hline $\begin{array}{l}\text { Heat shock, PBMC } \\
{[57-60]}\end{array}$ & $\begin{array}{l}\text { Heat stress Hsp70 in PBMC } \\
(2) \text { or with LPS and } \\
\text { training (1) or exercised in } \\
\text { heat acclimation (1) }\end{array}$ & $\begin{array}{l}\text { Hsp70 increase (3) } \\
\text { inhibited by } \\
\text { monensin, methyl- } \\
\text { beta-cyclodextrin, } \\
\text { and methylamine, } \\
\text { reduced in patients } \\
\text { with ARDS (2) }\end{array}$ & $\begin{array}{l}\text { Hsp70 decreased in } \\
\text { ARDS, recover } \varepsilon \delta \\
\text { over time (1) released } \\
\text { from lysosomal lipid } \\
\text { rafts (1) Reduced } \\
\text { apoptosis, TNF- } \alpha \text {, } \\
\text { IL-1b, increase } \delta \\
\text { CD14/CD16 (1) }\end{array}$ & $\begin{array}{l}\text { Protective (3) not } \\
\text { sufficient (1) }\end{array}$ \\
\hline
\end{tabular}

\begin{tabular}{|c|c|c|c|c|}
\hline & & (2) & CD14/CD16 (1) & \\
\hline $\begin{array}{l}\text { Recombinant } \\
\text { Hsp70-neutrophils, } \\
\text { monocytes [39] }\end{array}$ & $\begin{array}{l}\text { Preconditioning of myeloid } \\
\text { cells after LTA addition } \\
\text { with rHsp70 (1) }\end{array}$ & $\begin{array}{l}\text { Effect of human } \\
\text { recombinant Hsp70 } \\
\text { isolated from } \\
\text { Spodoptera cells on } \\
\text { neutrophil apoptosis } \\
\text { and expression of } \\
\text { CD11b/CD18 } \\
\text { receptors and TNF on } \\
\text { ROS production in } \\
\text { neutrophils and } \\
\text { monocytes }\end{array}$ & $\begin{array}{l}\text { Ameliorated reactive } \\
\text { oxygen species, } \\
\text { TNF- } \alpha, \text { CD11b/CD18, } \\
\text { did not normalize } \\
\text { apoptosis (1) }\end{array}$ & Protective (1) \\
\hline $\begin{array}{l}\text { Glutamine-[61]- } \\
\text { lymphocytes } \\
{[62]}\end{array}$ & $\begin{array}{l}\text { Glutamine-PBMCs (1) or } \\
\text { lymphocytes (1) }\end{array}$ & $\begin{array}{l}\text { After LPS-HS } \\
\text { increased 3-fold } \\
\text { Hsp70. A reduction of } \\
\text { Gln led to a } 40 \% \\
\text { lower Hsp70 level (2) }\end{array}$ & $\begin{array}{l}\text { Gln decreased TNF- } \alpha \\
\text { (1) Reduced Gln }= \\
\text { reduced Hsp70 = } \\
\text { impaired stress } \\
\text { response }(1)\end{array}$ & Protective (2) \\
\hline
\end{tabular}

also the adaptive immune response [71]. Thus, they have the capacity to elicit a pathogen-specific immune response [72] and to mediate the induction of peptide-specific immunity, eliciting potent $\mathrm{T}$ cell responses against the chaperoned peptide [73].
4.2. Experimental Hsp72 Studies. Hsp72 is the most highly induced stress protein in cells and tissues undergoing the stress response [74] and is central to the cytoprotective properties in patients with a variety of critical illnesses [52] or injuries [75]. Cell cycle components, regulatory proteins, and 
proteins in the mitogenic signal cascade may be protected by the molecular chaperone Hsp72 during periods of stress, by impairing proteasomal degradation of IkappaBalpha $(\mathrm{I} \kappa \mathrm{Ba})$ [47]. In addition, binding of Hsp72 to the Ser/Thr protein kinase IRE1a enhances the IREla/X-box binding protein $\mathrm{XBP} 1$ signaling at the endoplasmic reticulum and inhibits endoplasmic reticulum stress-induced apoptosis [76]. Thus, increased expression of Hsp72 by gene transfer/transfection has been demonstrated to confer protection against in vitro toxicity secondary to lethal hyperthermia [77], endotoxin [78], nitric oxide [79], hyperoxia [80], lung inflammation and injury [81], and in vivo ischemia-reperfusion injury [82]. On the contrary, microinjection of anti-Hsp72 antibody into cells impaired their ability to achieve thermotolerance [83].

We showed that in septic animal models, all reported Hsp72 induction methods increased intracellular Hsp72; this was associated with reduced proinflammatory cytokines, decreased organ damage, clinical improvement, and enhanced survival. Analysis of reviewed studies showed differed methodology approaching the Hsp72 biological and/ or genetic implication in the sepsis process.

4.2.1. Transgenic Animals. When challenged with systemic endotoxin, HSF1-deficient [84] or Hsp722-/- mice [49] had increased apoptosis and mortality compared to wild-type (WT) mice. Hsp72 expression was also required for Gln's protective effects on survival and tissue injury [34], an effect not seen in $H s p 72^{-/-}$mice [85]. On the contrary, using transgenic mice overexpressing the human Hspa12b gene, Hsp72 attenuated the endotoxin-induced cardiac dysfunction and leucocyte infiltration into the myocardium [51].

\subsubsection{Hsp72 Overexpression with Adenovirus Injection} (AdHSP). Hsp72 overexpression with adenovirus injection prevented the LPS-induced increase in tumor necrosis factoralpha (TNF $\alpha$ ) and IL- 6 levels associated with inhibited $\mathrm{I} \kappa \mathrm{B} \alpha$ degradation [36] through $\mathrm{NF}-\kappa \mathrm{B}$ pathway [47]. Increases in levels of Hsp72 by gene transfection attenuated LPS- or TNF $\alpha$-induced high mobility group box protein-1 (HMGB1) cytoplasmic translocation and release [12], decreased inducible NO synthase (iNOS) messenger RNA expression [45], and protected cells from programmed cell death [46]. Thus, AdHSP protected against sepsis-induced lung injury [86] by reducing nuclear caspase-3 [87], prevented alveolar type II cell proliferation [88], and improved short-term survival following CLP [89].

4.2.3. Exogenous Hsp72. At the cellular level, Hsp72 preparations not only inhibited LPS-induced reactive oxygen species production and decreased NO expression in macrophages, but they also partially normalized the disturbed neutrophil apoptosis [37]. Prophylactic administration of exogenous human Hsp72 normalized inflammatory responses [38], limited host tissue damage [48], and reduced mortality rates [39]. Liposomal transfer of Hsp72 into the myocardium abolished LPS-induced contractile dysfunction [44], reduced mortality rates, and modified hemostasis and hemodynamics [40]. Intestinal Hsp72 overexpression reversed toll-like receptor
(TLR)-4-induced cytokines and enterocyte apoptosis and prevented and treated experimental necrotizing enterocolitis [50]. Thus, mammalian Hsp72 appears to be an attractive target in therapeutic strategies designed to stimulate endogenous protective mechanisms against many deleterious consequences of septic shock by accelerating the functional recovery of susceptible organs in humans $[40,90]$.

4.2.4. Glutamine. Although Gln has little effect under basal conditions [43], endotoxin-treated animals given Gln exhibited dramatic increases in tissue Hsp72 expression [26], marked reduction of end-organ damage [28], attenuation of cytokine release [41] and peroxide biosynthesis, and improved vascular reactivity [29] associated with a significant decrease in mortality [91]. The molecular mechanism of Gln-induced Hsp72 expression appears to be mediated via enhancement of O-linked $\beta$ - $\mathrm{N}$-acetylglucosamine modification and subsequently to increased levels of endonuclear HSF1 expression [43] and HSF1 transcription activity [42].

In a recent study, septic mice with Gln administration showed less severe damage to the kidneys and exhibited decreased HMGB1 and TLR4 in kidney tissues [35]. In Gln-treated rats, lung Hsp72 and HSF1-p expressions were enhanced [32, 92], lung HMGB1 expression and NF- $\kappa$ B DNAbinding activity were suppressed, and ARDS was attenuated and survival improved [33]. By inducing Hsp72, Gln attenuated LPS-induced cardiomyocyte damage [42] and left ventricular dysfunction [27] whereas Gln-treated sheep had a greater increase in myocardial Hsp72 immunoreactivity without aggravating the hyperdynamic circulation after endotoxemia [31]. In a rat brain model of endotoxemia, Gln upregulated the expression of Hsp72 and decreased the magnitude of apoptosis by inhibiting the translocation of NF$\kappa \mathrm{B}$ from the cytoplasm to the nucleus [30].

4.2.5. Hyperthermic Heat Shock. Subjected to a brief hyperthermic heat shock, Hsp72 conferred protection against sepsis-related circulatory fatality via inhibition of iNOS gene expression through prevention of NF- $\kappa \mathrm{B}$ activation in cellular processes that included prevention of $\mathrm{I} \kappa \mathrm{B}$ kinase activation [25] and inhibition of $\mathrm{I} \kappa \mathrm{B} \alpha$ degradation [20]. Also, Hsp72 induction by thermal pretreatment [21] attenuated proinflammatory cytokines [22] and improved survival in the LPSinduced systemic inflammation model, potentially involving Hsp-mediated inhibition of HMGB1 secretion [23]. A HS response induction of Hsp72 mRNA and protein expression in the lung has been shown to be associated with reduced lung injury [18], improved lung function [93], and survival [94].

Heat shock pretreatment could also attenuate the electrocortical dysfunction in rats with LPS-induced septic response, suggesting that HS induced Hsp72 might potentially be used to prevent septic encephalopathy in sepsis [24]. Similarly, HS treatment led to Hsp72 overexpression and preserved the expression of the enzyme mitochondrial cytochrome c oxidase complex associated with the minimization of ultrastructural deformities during sepsis [19]. Interestingly, Gln increased DNA binding of HSF1 in HS 
cells but in its absence ornithine was able to rescue the heatinduced DNA binding of HSF1 [43].

4.3. Human Studies. Although the release of the Hsp72 in sepsis serves as a host impending danger signal to neighboring cells and might exert a cytoprotective function at low serum levels, it might also potentiate an already active host immune response leading to poor outcome once a certain critical threshold is attained. Such a sensitive balance could be an explanation of the surprising finding of this study, showing that only $16.7 \%$ of the 6 human septic studies demonstrated an Hsp72 protective effect compared to $95.8 \%$ protection shown in the 41 septic animal studies. In addition, by experimentally studying healthy individuals rather than patients in a real clinical setting, human studies mix up mild molecular reactions to stress with severe infectious systemic inflammatory response syndrome (SIRS), being thereby unconvincing and unable to verify results of experimentally controlled septic animal models.

\subsubsection{Intracellular Hsp72: In Vitro Studies (Cell Models).} Human in vitro studies, mainly examining intracellular Hsp72 expression in hPBMC or hPMNL in patients and healthy individuals by using HS, Gln, exogenous Hsp72, and Hsp72 inhibitors or agonists, are inconclusive [57]. Thus, although Gln infusion altered neither endotoxin-induced systemic inflammation nor early expression of Hsp72 in isolated PBMCs in healthy volunteers [53], inducibility of ex vivo Hsp72 was impaired in peripheral blood lymphocytes of patients with severe sepsis [95], possibly contributing to immune dysfunction of $\mathrm{T}$ and $\mathrm{B}$ lymphocyte responses in resisting infection in severe sepsis [56].

Enhanced Hsp72 response in endurance-trained individuals, however, improved heat tolerance through both anti-inflammatory and antiapoptotic mechanisms [58]. Also, rHsp72 preconditioning ameliorated reactive oxygen species, TNF $\alpha$, and CD11b/CD18 adhesion receptor expression after lipoteichoic acid addition [39]. Sepsis was shown to enhance expression of iHsp72 in PBMCs correlated to plasma TNF $\alpha$ concentrations [54] and in activated PMNLs, in which oxidative activity was increased and apoptosis was inhibited [55]. Similarly, using various Gln doses, proinflammatory cytokine release could directly be attenuated in PBMCs through enhancement of Hsp72 expression [61]. Overexpression of Hsp72 attenuated NF- $\kappa$ B activation and proinflammatory cytokine release $[88,96]$, inhibited LPS-mediated apoptosis, and protected lung epithelial cells [80] and pulmonary artery endothelial cells from oxidant-mediated [97] and inflammation-induced lung injury [59].

4.3.2. Extracellular Hsp72: In Vivo Studies (Serum Hsp). Although PBMC Hsp72 expression was shown to be markedly decreased in critically ill septic patients [56], a significant increase in serum Hsp72 levels was reported in children with septic shock [52]. Extracellular Hsp72, reflected by increased serum levels, was also evident in children with acute lung injury [81] or following cardiopulmonary bypass [98]. Results of a recent adult study also indicated that increased serum Hsp72 is associated with mortality in sepsis [15]. Worse outcome associated with extracellular Hsp72 has also been reported in coronary artery disease [99], liver disease [90], sickle cell disease vasoocclusive crisis [100], and preeclampsia [101].

Heat shock proteins are markedly induced in response to a diverse range of cellular insults, being a reliable danger marker of cell stress [102]. Thus, extracellular Hsps act as a "danger signal," activating immune-competent cells through LPS TLR4/CD14-dependent signaling [103]. According to the "danger hypothesis," the release of stress proteins from severely stressed or damaged cells serves as a host impending danger signal to neighboring cells [104]. They are released in a nonspecific manner from dying, necrotic cells [105] or from viable cells release in a specific and inhibitable manner [106, 107]. Using viable cell counts and lactate dehydrogenase the release of Hsp72 was shown to not be due to cellular damage [60]. Recent studies suggest that Hsp72 is actively released via an exosome-dependent nonclassical protein secretory pathway, possibly involving lysosomal lipid rafts [108]. Immune cell receptors capture Hsps released from necrotic cells or Hsp-containing exosomes [109], and receptor engagement by Hsp72 increases dendritic cell production of TNF $\alpha$, IL-1b, IL6 , and chemokine [110]. The host innate immune response occurs through a NF- $\kappa \mathrm{B}$-dependent proinflammatory gene expression via TLR4 and TLR2 [111], similar to a LPSmediated signal transduction [112].

4.4. Factors Influencing Heat Shock Proteins Protective Role in Sepsis. Recent work demonstrated that febrile-range temperatures achieved during sepsis and noninfectious SIRS correlated with detectable changes in stress gene expression in vivo (whole blood messenger RNA), thereby suggesting that fever can activate Hsp72 gene expression and modify innate immune responses [113]. Hsp72 serum levels may also be modulated according to the patient oxidant status [15] and prevent excessive gut apoptosis and inflammation in an age-dependent response to sepsis [49]. Importantly, Hsp72 inhibited LPS-induced NO release but only partially reduced the LPS increased expression of iNOS mRNA and exhibited LPS-induced NF- $\kappa$ B DNA binding and LPS tolerance; in contrast, HS inhibited LPS-induced NF- $\kappa$ B and HSF1 activity whereas HSF1 inhibited NF- $\kappa$ B DNA binding [45]!

A significant body of preexisting literature has hypothesized a relationship between Hsp72 expression and Gln's protection in both in vitro and in vivo settings $[32,43,62,114$, 115]. Pioneer studies showed that Gln supplementation could attenuate lethal heat and oxidant injury and increase Hsp72 expression in intestinal epithelial cells [116-118]. Compared, however, with whey protein supplementation in a randomized, double-blinded, comparative effectiveness trial, zinc, selenium, Gln, and intravenous metoclopramide conferred no advantage in the immune-competent population [6]. In addition, we recently showed that although apparently safe in animal models (pups), premature infants, and critically ill children, glutamine supplementation did not reduce mortality or late onset sepsis [119]. Methodological problems noted in the reviewed randomized experimental and clinical 
trials [119] should therefore be seriously considered in any future well-designed large blinded randomized controlled trial involving glutamine supplementation in severe sepsis.

Drug interactions were also shown either to suppress Hsp72 protective effects exacerbating therefore drug-induced side effects or to induce Hsp72 beneficial effects by suppressing drug-induced exacerbations. Thus, it was recently shown that bleomycin-induced pulmonary fibrosis is mediated by suppression of pulmonary expression of Hsp72 whereas an inducer of Hsp72 expression, such as geranylgeranylacetone, could be therapeutically beneficial for the treatment of gefitinib-induced pulmonary fibrosis [120].

Finally, critically ill patients display variable physiologic responses when stressed; gene association studies have recently been employed to explain this variability. Genetic variants of Hsp72 have also been associated with the development of septic shock in patients [121, 122]. Thus, the specific absence of Hsp72.1/3 gene expression can lead to increased mortality after septic insult [85].

4.5. Limitations of the Study. The major problem that limits the comparability with human sepsis is the fact that in most cases of animal models, various forms of preconditioning were employed. This approach is nonspecific, and only a minor amount (about 10\%) used genetically modified animals. Accordingly, important differences between cell and/or animal models versus clinical studies have been noted several times with various inflammatory pathways and have been written about extensively in the literature $[123,124]$. To the best of our knowledge, however, such discrepancies have not been summarized in detail in the context of Hsp72 and sepsis; in our opinion, these findings might be helpful for cautiously interpreting experimental data in the critical care field.

\section{Conclusions}

Heat shock proteins are molecular chaperokines that prevent the formation of nonspecific protein aggregates and exhibit sophisticated protection mechanisms. Experimental studies have repeatedly shown a strong molecular, biological, and clinical protective effect for Hsp72 in sepsis. Once again, clinical studies are inconclusive, varying from a protective in vitro effect to an in vivo Hsp72-mortality association. Possible influences by severity of disease-related factors, genetic variants, oxidant status, and unpredictable interventions such as those of temperature control, nutritional (glutamine) immune-enhancing, or drug intervening effects may unpredictably influence the Hsp72 protection efficacy in sepsis. Our "comparative" study data demonstrate that cellprotection with exogenous Hsp72, Hsp72 genes, heat stress, or glutamine is associated with induction of Hsp72 and that new Hsp72 targeted pharmaconutrition may be an approach to activating the preconditioning response in sepsis in clinical practice. However, as this hypothetical study suggests, much more work is needed to clarify the cellular and molecular mechanisms in which Hsp72 signals "danger" and regulates immune function in response to sepsis.

\section{Conflict of Interests}

The authors declare that there is no conflict of interests regarding the publication of this paper.

\section{Acknowledgments}

This research has been cofinanced by the European Union (European Social Fund (ESF)) and Greek National Funds through the Operational Program "Education and Lifelong Learning" of the National Strategic Reference Framework (NSRF)-Research Funding Program: THALES.

\section{References}

[1] F. Dal-Pizzol, "Alternative activated macrophage: a new key for systemic inflammatory response syndrome and sepsis treatment?" Critical Care Medicine, vol. 32, no. 9, pp. 1971-1972, 2004.

[2] M. Z. Sadique, R. Grieve, D. A. Harrison, B. H. Cuthbertson, and K. M. Rowan, "Is Drotrecogin alfa (activated) for adults with severe sepsis, cost-effective in routine clinical practice?" Critical Care, vol. 15, no. 5, article R228, 2011.

[3] J. Carcillo, R. Holubkov, J. M. Dean et al., "Rationale and design of the pediatric critical illness stress-induced immune suppression (CRISIS) prevention trial," Journal of Parenteral and Enteral Nutrition, vol. 33, no. 4, pp. 368-374, 2009.

[4] A. J. Dare, A. R. J. Phillips, A. J. R. Hickey et al., "A systematic review of experimental treatments for mitochondrial dysfunction in sepsis and multiple organ dysfunction syndrome," Free Radical Biology and Medicine, vol. 47, no. 11, pp. 1517-1525, 2009.

[5] V. M. Ranieri, B. T. Thompson, P. S. Barie et al., "Drotrecogin alfa (activated) in adults with septic shock," The New England Journal of Medicine, vol. 366, no. 22, pp. 2055-2064, 2012.

[6] J. A. Carcillo, J. M. Dean, R. Holubkov et al., "The randomized comparative pediatric critical illness stress-induced immune suppression (CRISIS) prevention trial," Pediatric Critical Care Medicine, vol. 13, no. 2, pp. 165-173, 2012.

[7] J. T. Silver and E. G. Noble, "Regulation of survival gene hsp70," Cell stress \& chaperones, vol. 17, no. 1, pp. 1-9, 2012.

[8] B. Jiang, P. Liang, G. Deng, Z. Tu, M. Liu, and X. Xiao, "Increased stability of Bcl-2 in HSP70-mediated protection against apoptosis induced by oxidative stress," Cell Stress and Chaperones, vol. 16, no. 2, pp. 143-152, 2011.

[9] B. H. Lee, D. Inui, G. Y. Suh et al., "Association of body temperature and antipyretic treatments with mortality of critically ill patients with and without sepsis: multi-centered prospective observational study," Critical Care, vol. 16, no. 1, article R33, 2012.

[10] F. Schortgen, K. Clabault, S. Katsahian et al., "Fever control using external cooling in septic shock: a randomized controlled trial," American Journal of Respiratory and Critical Care Medicine, vol. 185, no. 10, pp. 1088-1095, 2012.

[11] J. D. Johnson and M. Fleshner, "Releasing signals, secretory pathways, and immune function of endogenous extracellular heat shock protein 72," Journal of Leukocyte Biology, vol. 79, no. 3, pp. 425-434, 2006.

[12] D. Tang, R. Kang, W. Xiao, H. Wang, S. K. Calderwood, and X. Xiao, "The anti-inflammatory effects of heat shock protein 72 involve inhibition of high-mobility-group box 1 release and proinflammatory function in macrophages," Journal of Immunology, vol. 179, no. 2, pp. 1236-1244, 2007. 
[13] S. K. Calderwood, S. S. Mambula, P. J. Gray Jr., and J. R. Theriault, "Extracellular heat shock proteins in cell signaling," FEBS Letters, vol. 581, no. 19, pp. 3689-3694, 2007.

[14] S. K. Calderwood and J. Gong, "Molecular chaperones in mammary cancer growth and breast tumor therapy," Journal of Cellular Biochemistry, vol. 113, no. 4, pp. 1096-1103, 2012.

[15] D. P. Gelain, M. A. De Bittencourt Pasquali, C. M. Comim et al., "Serum heat shock protein 70 levels, oxidant status, and mortality in sepsis," Shock, vol. 35, no. 5, pp. 466-470, 2011.

[16] Q. Xu, B. Metzler, M. Jahangiri, and K. Mandal, "Molecular chaperones and heat shock proteins in atherosclerosis," American Journal of Physiology, vol. 302, no. 3, pp. H506-H514, 2012.

[17] D. Moher, A. Liberati, J. Tetzlaff, and D. G. Altman, "Preferred reporting items for systematic reviews and meta-analyses: the PRISMA statement," Journal of Clinical Epidemiology, vol. 62, no. 10, pp. 1006-1012, 2009.

[18] J. Villar, S. P. Ribeiro, J. B. M. Mullen, M. Kuliszewski, M. Post, and A. S. Slutsky, "Induction of the heat shock response reduces mortality rate and organ damage in a sepsis-induced acute lung injury model," Critical Care Medicine, vol. 22, no. 6, pp. 914-921, 1994.

[19] H.-W. Chen, H.-T. Kuo, T.-S. Lu, S.-J. Wang, and R.-C. Yang, "Cytochrome c oxidase as the target of the heat shock protective effect in septic liver," International Journal of Experimental Pathology, vol. 85, no. 5, pp. 249-256, 2004.

[20] J. Y. H. Chan, C.-C. Ou, L.-L. Wang, and S. H. H. Chan, "Heat shock protein 70 confers cardiovascular protection during endotoxemia via inhibition of nuclear factor- $\kappa \mathrm{B}$ activation and inducible nitric oxide synthase expression in the rostral ventrolateral medulla," Circulation, vol. 110, no. 23, pp. 35603566, 2004.

[21] J. P. Ofenstein, S. Heidemann, A. Juett-Wilstermann, and A. Sarnaik, "Expression of stress proteins HSP 72 and HSP 32 in response to endotoxemia," Annals of Clinical and Laboratory Science, vol. 30, no. 1, pp. 92-98, 2000.

[22] E. K. Chu, S. P. Ribeiro, and A. S. Slutsky, "Heat stress increases survival rates in lipopolysaccharide-stimulated rats," Critical Care Medicine, vol. 25, no. 10, pp. 1727-1732, 1997.

[23] A. Hasegawa, H. Iwasaka, S. Hagiwara, and T. Noguchi, "Relationship between HMGB1 and tissue protective effects of HSP72 in a LPS-induced systemic inflammation model," Journal of Surgical Research, vol. 169, no. 1, pp. 85-91, 2011.

[24] L.-C. Lin, Y.-Y. Chen, W.-T. Lee, H.-L. Chen, and R.-C. Yang, "Heat shock pretreatment attenuates sepsis-associated encephalopathy in LPS-induced septic rats," Brain and Development, vol. 32, no. 5, pp. 371-377, 2010.

[25] C.-T. Lee, L. Zhong, T. A. Mace, and E. A. Repasky, "Elevation in body temperature to fever range enhances and prolongs subsequent responsiveness of macrophages to endotoxin challenge," PLoS ONE, vol. 7, no. 1, Article ID e30077, 2012.

[26] E. Mazloomi, N. H. Jazani, M. Sohrabpour, B. Ilkhanizadeh, and S. Shahabi, "Synergistic effects of glutamine and ciprofloxacin in reduction of Pseudomonas aeruginosa-induced septic shock severity," International Immunopharmacology, vol. 11, no. 12, pp. 2214-2219, 2011.

[27] G. Chen, T. G. Neilan, H. Chen et al., "Attenuation of lipopolysaccharide-mediated left ventricular dysfunction by glutamine preconditioning," Journal of Surgical Research, vol. 160, no. 2, pp. 282-287, 2010.

[28] P. E. Wischmeyer, M. Kahana, R. Wolfson, H. Ren, M. M. Musch, and E. B. Chang, "Glutamine induces heat shock protein and protects against endotoxin shock in the rat," Journal of Applied Physiology, vol. 90, no. 6, pp. 2403-2410, 2001.

[29] L. Jing, Q. Wu, and F. Wang, "Glutamine induces heat-shock protein and protects against Escherichia coli lipopolysaccharide-induced vascular hyporeactivity in rats," Critical Care, vol. 11, article R34, 2007.

[30] Y. J. Zhao, H. Wang, X. Liu, M. Sun, and H. Kazuhiro, "Protective effects of glutamine in a rat model of endotoxemia," Molecular Medicine Reports, vol. 6, no. 4, pp. 739-744, 2012.

[31] M. Scharte, H. A. Baba, H. Van Aken et al., "Alanyl-glutamine dipeptide does not affect hemodynamics despite a greater increase in myocardial heat shock protein 72 immunoreactivity in endotoxemic sheep," Journal of Nutrition, vol. 131, no. 5, pp. 1433-1437, 2001.

[32] K. D. Singleton, N. Serkova, V. E. Beckey, and P. E. Wischmeyer, "Glutamine attenuates lung injury and improves survival after sepsis: role of enhanced heat shock protein expression," Critical Care Medicine, vol. 33, no. 6, pp. 1206-1213, 2005.

[33] W. Y. Kwon, G. J. Suh, K. S. Kim et al., "Glutamine attenuates acute lung injury by inhibition of high mobility group box protein-1 expression during sepsis," British Journal of Nutrition, vol. 103, no. 6, pp. 890-898, 2010.

[34] K. D. Singleton and P. E. Wischmeyer, "Glutamine's protection against sepsis and lung injury is dependent on heat shock protein 70 expression," American Journal of Physiology, vol. 292, no. 5, pp. R1839-R1845, 2007.

[35] Y.-M. Hu, M.-H. Pai, C.-L. Yeh, Y.-C. Hou, and S.-L. Yeh, "Glutamine administration ameliorates sepsis-induced kidney injury by downregulating the high-mobility group box protein1-mediated pathway in mice," American Journal of Physiology, vol. 302, no. 1, pp. 150-158, 2012.

[36] K. Dokladny, R. Lobb, W. Wharton, T. Y. Ma, and P. L. Moseley, "LPS-induced cytokine levels are repressed by elevated expression of HSP70 in rats: possible role of NF- $\kappa$ B," Cell Stress and Chaperones, vol. 15, no. 2, pp. 153-163, 2010.

[37] E. Rozhkova, M. Yurinskaya, O. Zatsepina et al., "Exogenous mammalian extracellular HSP70 reduces endotoxin manifestations at the cellular and organism levels," Annals of the New York Academy of Sciences, vol. 1197, pp. 94-107, 2010.

[38] X. Su, J. B. Sykes, L. Ao, C. D. Raeburn, D. A. Fullerton, and X. Meng, "Extracellular heat shock cognate protein 70 induces cardiac functional tolerance to endotoxin: differential effect on TNF- $\alpha$ and ICAM-1 levels in heart tissue," Cytokine, vol. 51, no. 1, pp. 60-66, 2010.

[39] M. Vinokurov, V. Ostrov, M. Yurinskaya et al., "Recombinant human Hsp70 protects against lipoteichoic acid-induced inflammation manifestations at the cellular and organismal levels," Cell Stress \& Chaperones, vol. 17, no. 1, pp. 89-101, 2012.

[40] G. A. Kustanova, A. N. Murashev, V. L. Karpov et al., "Exogenous heat shock protein 70 mediates sepsis manifestations and decreases the mortality rate in rats," Cell Stress and Chaperones, vol. 11, no. 3, pp. 276-286, 2006.

[41] M. Liang, X. Wang, Y. Yuan, Q. Zhou, C. Tong, and W. Jiang, "Different effect of glutamine on macrophage tumor necrosis factor-alpha release and heat shock protein 72 expression in vitro and in vivo," Acta Biochimica et Biophysica Sinica, vol. 41, no. 2, pp. 171-177, 2009.

[42] J. Gong and L. Jing, "Glutamine induces heat shock protein 70 expression via O-GlcNAc modification and subsequent increased expression and transcriptional activity of heat shock factor-1," Minerva Anestesiologica, vol. 77, no. 5, pp. 488-495, 2011. 
[43] Y. Iwashita, T. Sakiyama, M. W. Musch, M. J. Ropeleski, H. Tsubouchi, and E. B. Chang, "Polyamines mediate glutaminedependent induction of the intestinal epithelial heat shock response," American Journal of Physiology, vol. 301, no. 1, pp. G181-G187, 2011.

[44] D. R. Meldrum, X. Meng, B. D. Shames et al., "Liposomal delivery of heat-shock protein 72 into the heart prevents endotoxininduced myocardial contractile dysfunction," Surgery, vol. 126, no. 2, pp. 135-141, 1999.

[45] M. Song, M. R. Pinsky, and J. A. Kellum, "Heat shock factor 1 inhibits nuclear factor- $\kappa \mathrm{B}$ nuclear binding activity during endotoxin tolerance and heat shock," Journal of Critical Care, vol. 23, no. 3, pp. 406-415, 2008.

[46] X. Z. Ding, X. R. Feng, R. H. Borschel et al., "HSP-70 mitigates LPS/SKI-induced cell damage by increasing sphingosine kinase 1 (SK1)," Prostaglandins and Other Lipid Mediators, vol. 92, no. 1-4, pp. 1-7, 2010.

[47] Y. G. Weiss, Z. Bromberg, N. Raj et al., "Enhanced heat shock protein 70 expression alters proteasomal degradation of $\mathrm{I} \kappa \mathrm{B}$ kinase in experimental acute respiratory distress syndrome," Critical Care Medicine, vol. 35, no. 9, pp. 2128-2138, 2007.

[48] M. I. Hirsh, N. Hashiguchi, Y. Chen, L. Yip, and W. G. Junger, "Surface expression of HSP72 by LPS-stimulated neutrophils facilitates $\gamma \delta$ T cell-mediated killing," European Journal of Immunology, vol. 36, no. 3, pp. 712-721, 2006.

[49] K. W. McConnell, A. C. Fox, A. T. Clark et al., "The role of heat shock protein 70 in mediating age-dependent mortality in sepsis," Journal of Immunology, vol. 186, no. 6, pp. 3718-3725, 2011.

[50] A. Afrazi, C. P. Sodhi, M. Good et al., "Intracellular heat shock protein-70 negatively regulates TLR4 signaling in the newborn intestinal epithelium," Journal of Immunology, vol. 188, no. 9, pp. 4543-4557, 2012.

[51] H. Zhou, J. Qian, C. Li et al., "Attenuation of cardiac dysfunction by HSPA12B in endotoxin-induced sepsis in mice through a PI3K-dependent mechanism," Cardiovascular Research, vol. 89, no. 1, pp. 109-118, 2011.

[52] D. S. Wheeler, L. E. Fisher Jr., J. D. Catravas, B. R. Jacobs, J. A. Carcillo, and H. R. Wong, "Extracellular hsp70 levels in children with septic shock," Pediatric Critical Care Medicine, vol. 6, no. 3, pp. 308-311, 2005.

[53] A. S. Andreasen, T. Pedersen-Skovsgaard, O. H. Mortensen, G. Van Hall, P. L. Moseley, and B. K. Pedersen, "The effect of glutamine infusion on the inflammatory response and HSP70 during human experimental endotoxaemia," Critical Care, vol. 13, no. 1, article R7, 2009.

[54] G. Delogu, L. Lo Bosco, M. Marandola et al., "Heat shock protein (HSP70) expression in septic patients," Journal of Critical Care, vol. 12, no. 4, pp. 188-192, 1997.

[55] N. Hashiguchi, H. Ogura, H. Tanaka et al., "Enhanced expression of heat shock proteins in activated polymorphonuclear leukocytes in patients with sepsis," Journal of Trauma, vol. 51, no. 6, pp. 1104-1109, 2001.

[56] S. Schroeder, J. Bischoff, L. E. Lehmann et al., "Endotoxin inhibits heat shock protein 70 (HSP7O) expression in peripheral blood mononuclear cells of patients with severe sepsis," Intensive Care Medicine, vol. 25, no. 1, pp. 52-57, 1999.

[57] F. Amorim, P. Yamada, R. Robergs, S. Schneider, and P. Moseley, "Effects of whole-body heat acclimation on cell injury and cytokine responses in peripheral blood mononuclear cells," European Journal of Applied Physiology, vol. 111, no. 8, pp. 16091618, 2011.
[58] G. A. Selkirk, T. M. McLellan, H. E. Wright, and S. G. Rhind, "Expression of intracellular cytokines, HSP72, and apoptosis in monocyte subsets during exertional heat stress in trained and untrained individuals," American Journal of Physiology, vol. 296, no. 3, pp. R575-R586, 2009.

[59] P. Durand, M. Bachelet, F. Brunet et al., "Inducibility of the $70 \mathrm{kD}$ heat shock protein in peripheral blood monocytes is decreased in human acute respiratory distress syndrome and recovers over time," American Journal of Respiratory and Critical Care Medicine, vol. 161, no. 1, pp. 286-292, 2000.

[60] C. Hunter-Lavin, E. L. Davies, M. M. F. V. G. Bacelar, M. J. Marshall, S. M. Andrew, and J. H. H. Williams, "Hsp70 release from peripheral blood mononuclear cells," Biochemical and Biophysical Research Communications, vol. 324, no. 2, pp. 511517, 2004.

[61] P. E. Wischmeyer, J. Riehm, K. D. Singleton et al., "Glutamine attenuates tumor necrosis factor- $\alpha$ release and enhances heat shock protein 72 in human peripheral blood mononuclear cells," Nutrition, vol. 19, no. 1, pp. 1-6, 2003.

[62] R. Oehler, E. Pusch, P. Dungel et al., "Glutamine depletion impairs cellular stress response in human leucocytes," British Journal of Nutrition, vol. 87, no. 1, pp. S17-S21, 2002.

[63] A. G. Pockley, M. Muthana, and S. K. Calderwood, "The dual immunoregulatory roles of stress proteins," Trends in Biochemical Sciences, vol. 33, no. 2, pp. 71-79, 2008.

[64] R. Voellmy, "On mechanisms that control heat shock transcription factor activity in metazoan cells," Cell Stress and Chaperones, vol. 9, no. 2, pp. 122-133, 2004.

[65] Y. Shi, D. D. Mosser, and R. I. Morimoto, "Molecular chaperones as HSF1-specific transcriptional repressors," Genes and Development, vol. 12, no. 5, pp. 654-666, 1998.

[66] J. Amin, J. Ananthan, and R. Voellmy, "Key features of heat shock regulatory elements," Molecular and Cellular Biology, vol. 8, no. 9, pp. 3761-3769, 1988.

[67] L. Pirkkala, P. Nykänen, and L. Sistonen, "Roles of the heat shock transcription factors in regulation of the heat shock response and beyond," FASEB Journal, vol. 15, no. 7, pp. 11181131, 2001.

[68] A. De Maio, "Heat shock proteins: facts, thoughts, and dreams," Shock, vol. 11, no. 1, pp. 1-12, 1999.

[69] E. W. Trotter, C. M.-F. Kao, L. Berenfeld, D. Botstein, G. A. Petsko, and J. V. Gray, "Misfolded proteins are competent to mediate a subset of the responses to heat shock in Saccharomyces cerevisiae," Journal of Biological Chemistry, vol. 277, no. 47, pp. 44817-44825, 2002.

[70] R. Voellmy, “Transduction of the stress signal and mechanisms of transcriptional regulation of heat shock/stress protein gene expression in higher eukaryotes," Critical Reviews in Eukaryotic Gene Expression, vol. 4, no. 4, pp. 357-401, 1995.

[71] M. P. Radsak, N. Hilf, H. Singh-Jasuja et al., "The heat shock protein Gp96 binds to human neutrophils and monocytes and stimulates effector functions," Blood, vol. 101, no. 7, pp. 28102815, 2003.

[72] A. G. Pockley, "Heat shock proteins as regulators of the immune response," Lancet, vol. 362, no. 9382, pp. 469-476, 2003.

[73] J. Robert, "Evolution of heat shock protein and immunity," Developmental and Comparative Immunology, vol. 27, no. 6-7, pp. 449-464, 2003.

[74] K. C. Kregel, "Invited review: heat shock proteins: modifying factors in physiological stress responses and acquired thermotolerance," Journal of Applied Physiology, vol. 92, no. 5, pp. 21772186, 2002. 
[75] Y. Lai, P. M. Kochanek, P. D. Adelson, K. Janesko, R. A. Ruppel, and R. S. B. Clark, "Induction of the stress response after inflicted and non-inflicted traumatic brain injury in infants and children," Journal of Neurotrauma, vol. 21, no. 3, pp. 229-237, 2004.

[76] S. Gupta, A. Deepti, S. Deegan, F. Lisbona, C. Hetz, and A. Samali, "HSP72 protects cells from ER stress-induced apoptosis via enhancement of IRE1 $\alpha$-xbp1 signaling through a physical interaction," PLoS Biology, vol. 8, no. 7, Article ID e1000410, 2010.

[77] G. C. Li, L. Li, Y.-K. Liu, J. Y. Mak, L. Chen, and W. M. F. Lee, "Thermal response of rat fibroblasts stably transfected with the human $70-\mathrm{kDa}$ heat shock protein-encoding gene," Proceedings of the National Academy of Sciences of the United States of America, vol. 88, no. 5, pp. 1681-1685, 1991.

[78] H. R. Wong, R. J. Mannix, J. M. Rusnak et al., "The Heat-shock response attenuates lipopolysaccharide-mediated apoptosis in cultured sheep pulmonary artery endothelial cells," American Journal of Respiratory Cell and Molecular Biology, vol. 15, no. 6, pp. 745-751, 1996.

[79] H. R. Wong, M. Ryan, I. Y. Menendez, A. Denenberg, and J. R. Wispé, "Heat shock protein induction protects human respiratory epithelium against nitric oxide-mediated cytotoxicity," Shock, vol. 8, no. 3, pp. 213-218, 1997.

[80] H. R. Wong, I. Y. Menendez, M. A. Ryan, A. G. Denenberg, and J. R. Wispé, "Increased expression of heat shock protein70 protects A549 cells against hyperoxia," American Journal of Physiology, vol. 275, no. 4, pp. L836-L841, 1998.

[81] D. S. Wheeler and H. R. Wong, "Heat shock response and acute lung injury," Free Radical Biology and Medicine, vol. 42, no. 1, pp. 1-14, 2007.

[82] M. Hiratsuka, B. N. Mora, M. Yano, T. Mohanakumar, and G. A. Patterson, "Gene transfer of heat shock protein 70 protects lung grafts from ischemia-reperfusion injury," Annals of Thoracic Surgery, vol. 67, no. 5, pp. 1421-1427, 1999.

[83] K. T. Riabowol, L. A. Mizzen, and W. J. Welch, "Heat shock is lethal to fibroblasts microinjected with antibodies against hsp70," Science, vol. 242, no. 4877, pp. 433-436, 1988.

[84] D. R. McMillan, X. Xiao, L. Shao, K. Graves, and I. J. Benjamin, "Targeted disruption of heat shock transcription factor 1 abolishes thermotolerance and protection against heat-inducible apoptosis," Journal of Biological Chemistry, vol. 273, no. 13, pp. 7523-7528, 1998.

[85] K. D. Singleton and P. E. Wischmeyer, "Effects of HSP70.1/3 gene knockout on acute respiratory distress syndrome and the inflammatory response following sepsis," American Journal of Physiology, vol. 290, no. 5, pp. L956-L961, 2006.

[86] Y. G. Weiss, A. Maloyan, J. Tazelaar, N. Raj, and C. S. Deutschman, "Adenoviral transfer of HSP-70 into pulmonary epithelium ameliorates experimental acute respiratory distress syndrome," Journal of Clinical Investigation, vol. 110, no. 6, pp. 801-806, 2002.

[87] G. Aschkenasy, Z. Bromberg, N. Raj, C. S. Deutschman, and Y. G. Weiss, "Enhanced Hsp70 expression protects against acute lung injury by modulating apoptotic pathways," PLOS ONE, vol. 6, no. 11, Article ID e26956, 2011.

[88] Y. G. Weiss, A. Bouwman, B. Gehan, G. Schears, N. Raj, and C. S. Deutschman, "Cecal ligation and double puncture impairs heat shock protein 70 (HSP-70) expression in the lungs of rats," Shock, vol. 13, no. 1, pp. 19-23, 2000.

[89] Z. Bromberg, N. Raj, P. Goloubinoff, C. S. Deutschman, and Y. G. Weiss, "Enhanced expression of 70-kilodalton heat shock protein limits cell division in a sepsis-induced model of acute respiratory distress syndrome," Critical Care Medicine, vol. 36, no. 1, pp. 246-255, 2008.

[90] F. Kimura, H. Itoh, S. Ambiru et al., "Circulating heat-shock protein 70 is associated with postoperative infection and organ dysfunction after liver resection," American Journal of Surgery, vol. 187, no. 6, pp. 777-784, 2004.

[91] P. E. Wischmeyer, M. Kahana, R. Wolfson, H. Ren, M. M. Musch, and E. B. Chang, "Glutamine reduces cytokine release, organ damage, and mortality in a rat model of endotoxemia," Shock, vol. 16, no. 5, pp. 398-402, 2001.

[92] K. D. Singleton, V. E. Beckey, and P. E. Wischmeyer, "Glutamine prevents activation of NF- $\kappa \mathrm{B}$ and stress kinase pathways, attenuates inflammatory cytokine release, and prevents acute respiratory distress syndrome (ARDS) following sepsis," Shock, vol. 24, no. 6, pp. 583-589, 2005.

[93] S. P. Ribeiro, K. Rhee, L. Tremblay, R. Veldhuizen, J. F. Lewis, and A.S. Slutsky, "Heat stress attenuates ventilator-induced lung dysfunction in an ex vivo rat lung model," American Journal of Respiratory and Critical Care Medicine, vol. 163, no. 6, pp. 14511456, 2001.

[94] S. P. Ribeiro, J. Villar, G. P. Downey, J. D. Edelson, and A. S. Slutsky, "Sodium arsenite induces heat shock protein-72 kilodalton expression in the lungs and protects rats against sepsis," Critical Care Medicine, vol. 22, no. 6, pp. 922-929, 1994.

[95] S. Schroeder, C. Lindemann, A. Hoeft et al., "Impaired inducibility of heat shock protein 70 in peripheral blood lymphocytes of patients with severe sepsis," Critical Care Medicine, vol. 27, no. 6, pp. 1080-1084, 1999.

[96] D. L. Feinstein, E. Galea, D. A. Aquino, G. C. Li, H. Xu, and D. J. Reis, "Heat shock protein 70 suppresses astroglialinducible nitric-oxide synthase expression by decreasing NF $\kappa \mathrm{B}$ activation," Journal of Biological Chemistry, vol. 271, no. 30, pp. 17724-17732, 1996.

[97] H. R. Wong, M. Ryan, S. Gebb, and J. R. Wispé, "Selective and transient in vitro effects of heat shock on alveolar type II cell gene expression," American Journal of Physiology, vol. 272, no. 1, pp. L132-L138, 1997.

[98] B. Dybdahl, A. Wahba, R. Haaverstad et al., "On-pump versus off-pump coronary artery bypass grafting: more heat-shock protein 70 is released after on-pump surgery," European Journal of Cardio-thoracic Surgery, vol. 25, no. 6, pp. 985-992, 2004.

[99] B. Dybdahl, S. A. Slørdahl, A. Waage, P. Kierulf, T. Espevik, and A. Sundan, "Myocardial ischaemia and the inflammatory response: release of heat shock protein 70 after myocardial infarction," Heart, vol. 91, no. 3, pp. 299-304, 2005.

[100] A. H. Adewoye, E. S. Klings, H. W. Farber et al., "Sickle cell vasoocclusive crisis induces the release of circulating serum heat shock protein-70," American Journal of Hematology, vol. 78, no. 3, pp. 240-242, 2005.

[101] A. Fukushima, H. Kawahara, C. Isurugi et al., "Changes in serum levels of heat shock protein 70 in preterm delivery and pre-eclampsia," Journal of Obstetrics and Gynaecology Research, vol. 31, no. 1, pp. 72-77, 2005.

[102] R. Oberbeck, H. Deckert, J. Bangen, P. Kobbe, and D. Schmitz, "Dehydroepiandrosterone: a modulator of cellular immunity and heat shock protein 70 production during polymicrobial sepsis," Intensive Care Medicine, vol. 33, no. 12, pp. 2207-2213, 2007.

[103] R. Aneja, K. Odoms, K. Dunsmore, T. P. Shanley, and H. R. Wong, "Extracellular heat shock protein-70 induces endotoxin 
tolerance in THP-1 cells," Journal of Immunology, vol. 177, no. 10, pp. 7184-7192, 2006.

[104] A. Lang, D. Benke, F. Eitner et al., "Heat shock protein 60 is released in immune-mediated glomerulonephritis and aggravates disease: in vivo evidence for an immunologic danger signal," Journal of the American Society of Nephrology, vol. 16, no. 2, pp. 383-391, 2005.

[105] S. Basu, R. J. Binder, R. Suto, K. M. Anderson, and P. K. Srivastava, "Necrotic but not apoptotic cell death releases heat shock proteins, which deliver a partial maturation signal to dendritic cells and activate the NF- $\kappa \mathrm{B}$ pathway," International Immunology, vol. 12, no. 11, pp. 1539-1546, 2000.

[106] G. I. Lancaster, K. Møller, B. Nielsen, N. H. Secher, M. A. Febbraio, and L. Nybo, "Exercise induces the release of heat shock protein 72 from the human brain in vivo," Cell Stress and Chaperones, vol. 9, no. 3, pp. 276-280, 2004.

[107] I. Guzhova, K. Kislyakova, O. Moskaliova et al., "In vitro studies show that Hsp70 can be released by glia and that exogenous Hsp70 can enhance neuronal stress tolerance," Brain Research, vol. 914, no. 1-2, pp. 66-73, 2001.

[108] G. I. Lancaster and M. A. Febbraio, "Exosome-dependent trafficking of HSP70: a novel secretory pathway for cellular stress proteins," Journal of Biological Chemistry, vol. 280, no. 24, pp. 23349-23355, 2005.

[109] A. Clayton, A. Turkes, H. Navabi, M. D. Mason, and Z. Tabi, "Induction of heat shock proteins in B-cell exosomes," Journal of Cell Science, vol. 118, no. 16, pp. 3631-3638, 2005.

[110] A. Asea, S.-K. Kraeft, E. A. Kurt-Jones et al., "HSP70 stimulates cytokine production through a CD 14-dependant pathway, demonstrating its dual role as a chaperone and cytokine," Nature Medicine, vol. 6, no. 4, pp. 435-442, 2000.

[111] A. Asea, M. Rehli, E. Kabingu et al., "Novel signal transduction pathway utilized by extracellular HSP70. Role of toll-like receptor (TLR) 2 and TLR4," Journal of Biological Chemistry, vol. 277, no. 17, pp. 15028-15034, 2002.

[112] K. M. Anderson and P. K. Srivastava, "Heat, heat shock, heat shock proteins and death: a central link in innate and adaptive immune responses," Immunology Letters, vol. 74, no. 1, pp. 3539, 2000.

[113] L. A. Sonna, L. Hawkins, M. E. Lissauer et al., "Core temperature correlates with expression of selected stress and immunomodulatory genes in febrile patients with sepsis and noninfectious SIRS," Cell stress \& chaperones, vol. 15, no. 1, pp. 55-66, 2010.

[114] T. R. Ziegler, L. G. Ogden, K. D. Singleton et al., "Parenteral glutamine increases serum heat shock protein 70 in critically ill patients," Intensive Care Medicine, vol. 31, no. 8, pp. 1079-1086, 2005.

[115] T. Grau, A. Bonet, E. Miñambres et al., "The effect of l-alanyll-glutamine dipeptide supplemented total parenteral nutrition on infectious morbidity and insulin sensitivity in critically ill patients," Critical Care Medicine, vol. 39, no. 6, pp. 1263-1268, 2011.

[116] P. E. Wischmeyer, M. W. Musch, M. B. Madonna, R. Thisted, and E. B. Chang, "Glutamine protects intestinal epithelial cells: role of inducible HSP70," American Journal of Physiology, vol. 272, no. 4, pp. G879-G884, 1997.

[117] M. W. Musch, D. Hayden, K. Sugi, D. Straus, and E. B. Chang, "Cell-specific induction of hsp72-mediated protection by glutamine against oxidant injury in IEC18 cells," Proceedings of the Association of American Physicians, vol. 110, no. 2, pp. 136139, 1998.
[118] A. Chow and R. Zhang, "Glutamine reduces heat shock-induced cell death in rat intestinal epithelial cells," Journal of Nutrition, vol. 128, no. 8, pp. 1296-1301, 1998.

[119] E. Briassouli and G. Briassoulis, "Glutamine randomized studies in early life: the unsolved riddle of experimental and clinical studies," Clinical and Developmental Immunology, vol. 2012, Article ID 749189, 17 pages, 2012.

[120] T. Namba, K.-I. Tanaka, T. Hoshino, A. Azuma, and T. Mizushima, "Suppression of expression of heat shock protein 70 by gefitinib and its contribution to pulmonary fibrosis," PLoS ONE, vol. 6, no. 11, Article ID e27296, 2011.

[121] C. Kee, K. Y. Cheong, K. Pham, G. W. Waterer, and S. E. L. Temple, "Genetic variation in heat shock protein 70 is associated with septic shock: narrowing the association to a specific haplotype," International Journal of Immunogenetics, vol. 35, no. 6, pp. 465-473, 2008.

[122] G. W. Waterer, L. ElBahlawan, M. W. Quasney, Q. Zhang, L. A. Kessler, and R. G. Wunderink, "Heat shock protein 70-2 + 1267 AA homozygotes have an increased risk of septic shock in adults with community-acquired pneumonia," Critical Care Medicine, vol. 31, no. 5, pp. 1367-1372, 2003.

[123] K. A. Shirey, W. Lai, A. J. Scott et al., "The TLR4 antagonist Eritoran protects mice from lethal influenza infection," Nature, vol. 497, no. 7450, pp. 498-502, 2013.

[124] S. M. Opal, P. F. Laterre, B. Francois et al., "Effect of eritoran, an antagonist of MD2-TLR4, on mortality in patients with severe sepsis: the ACCESS randomized trial," JAMA, vol. 309, no. 11, pp. 1154-1162, 2013. 


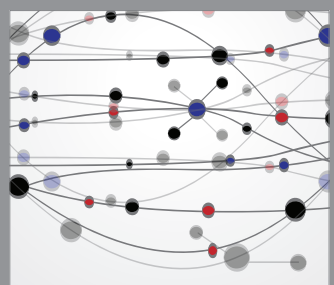

The Scientific World Journal
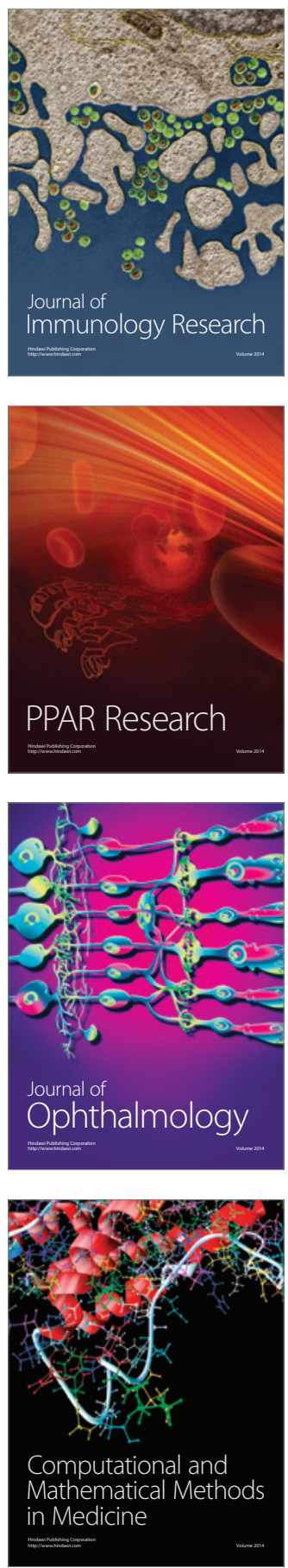

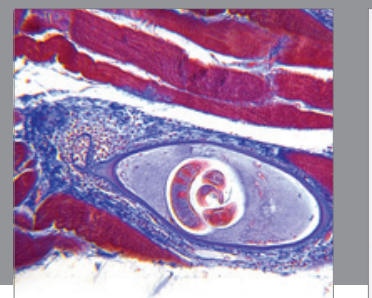

Gastroenterology

Research and Practice
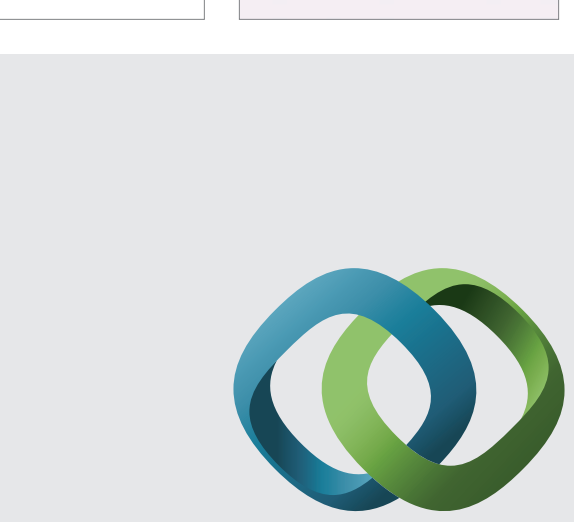

\section{Hindawi}

Submit your manuscripts at

http://www.hindawi.com
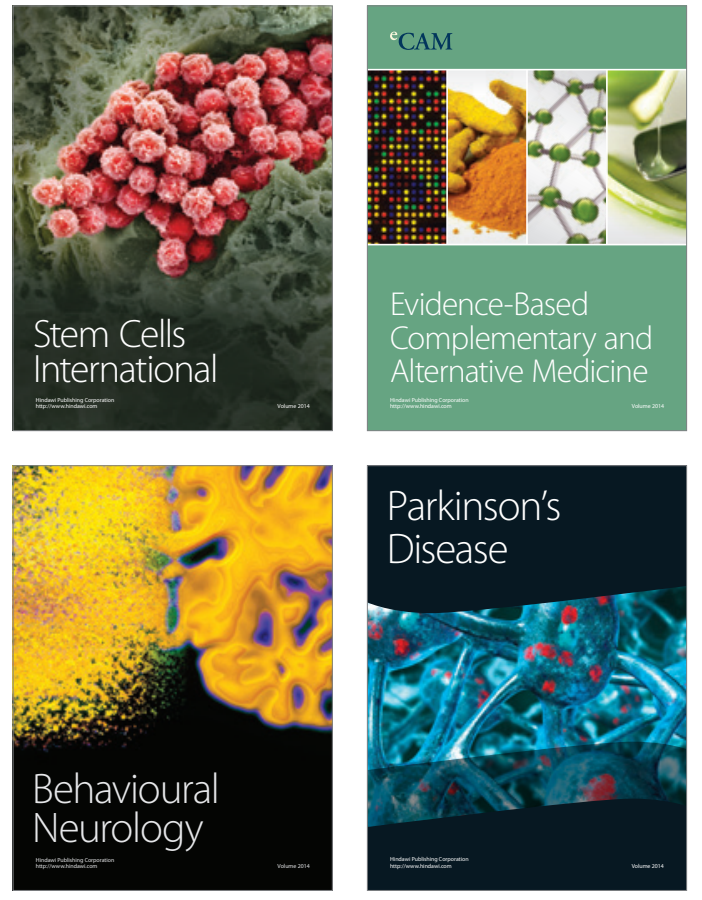
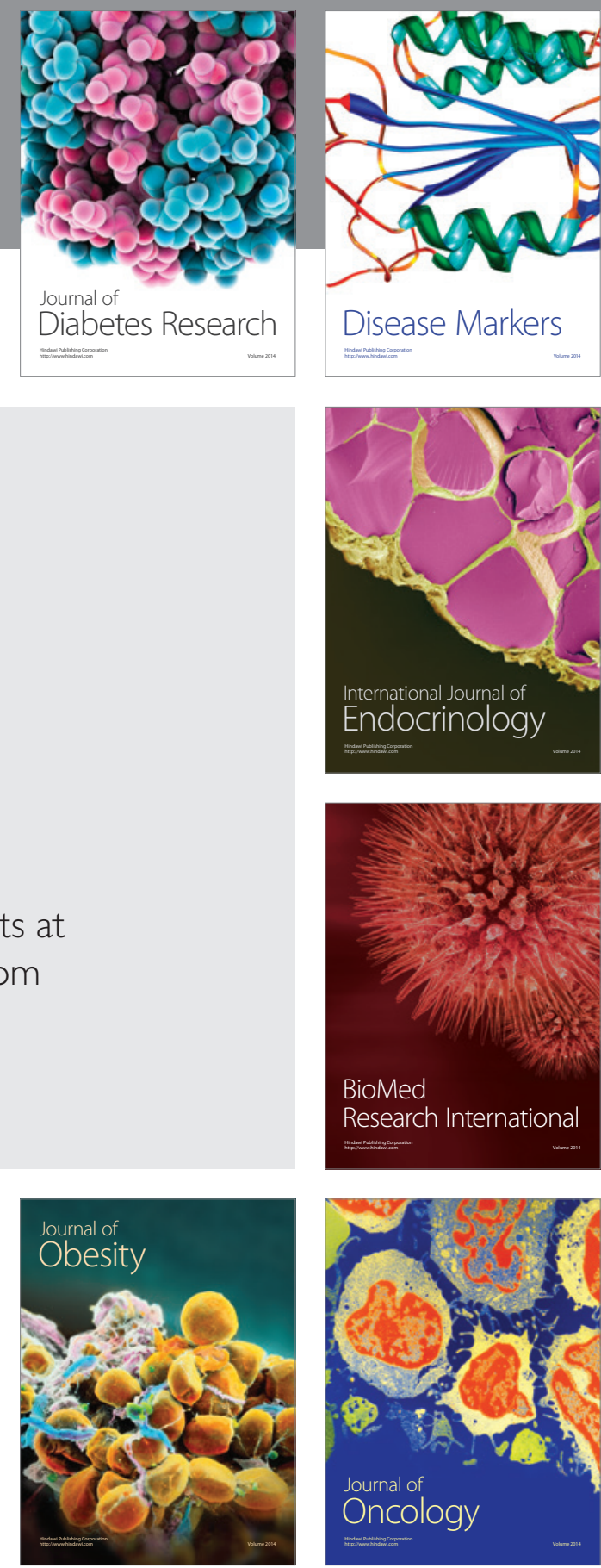

Disease Markers
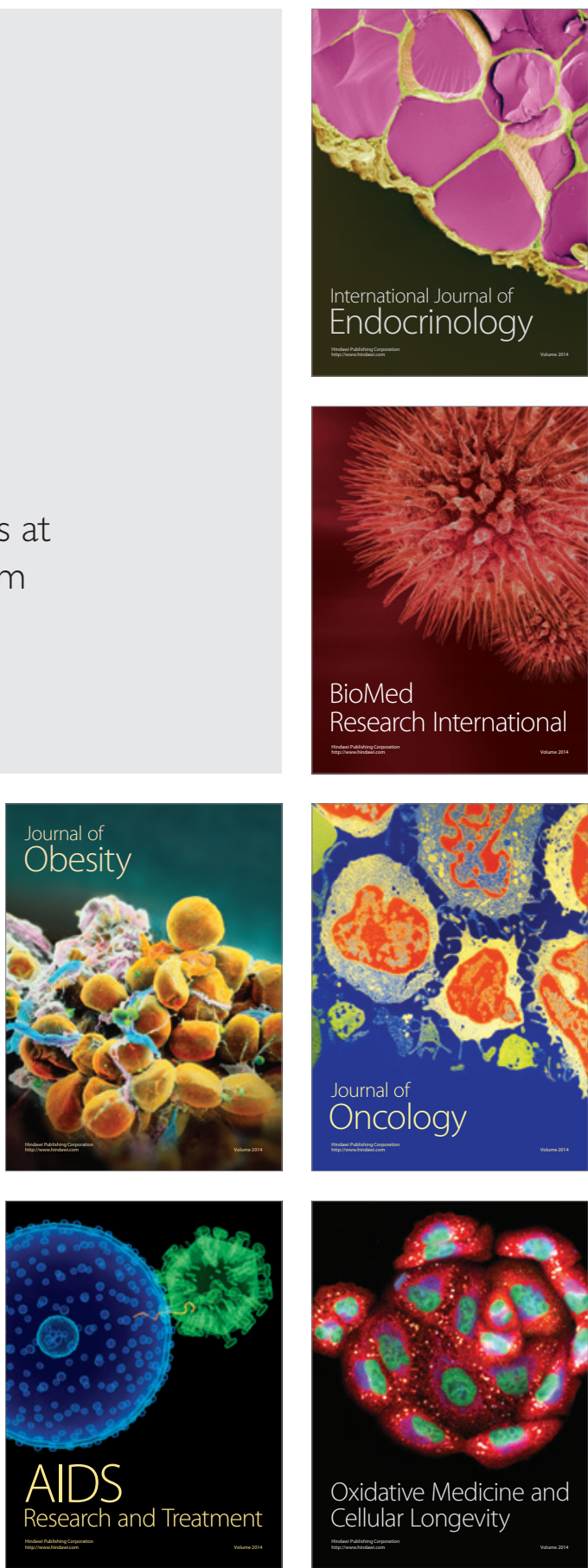